\title{
Da devoção à explosão: manifestações populares de adesão e contestação à estatuária urbana de Lima (1859-1921)
}

\author{
Rafael Dias Scarelli ${ }^{1}$
}

\begin{abstract}
Resumo: O objetivo deste artigo é abordar a recepção aos monumentos públicos erigidos em Lima pela população citadina entre 1859 e 1921. Nossas balizas cronológicas são delimitadas, respectivamente, pela inauguração do primeiro monumento escultórico da cidade, dedicado a Bolívar, e a inauguração do Monumento a San Martín, no bojo das comemorações do Centenário da Independência. Nesse esforço, buscaremos não apenas pelas manifestações de aparente incompreensão e de contestação ao projeto escultórico em curso na capital peruana, mas também pelas manifestações de apoio e adesão, sobretudo nas cerimônias de inauguração. É nosso objetivo também desvendar as estratégias mobilizadas pelo Estado peruano a fim de difundir entre a população limenha práticas de respeitabilidade frente às esculturas ao afirmar posturas contemplativas para os observadores. Partimos de um conjunto heterogêneo de fontes, tais como guia de viagem, postais, artigos publicados na imprensa e ofícios trocados entre autoridades municipais.
\end{abstract}

Palavras-chave: Lima, monumentos públicos, recepção.

\section{From devotion to explosion: popular manifestations of adhesion and contestation to Lima's urban statuary (1859-1921)}

\begin{abstract}
This article analyzes the reception of public monuments erected in Lima between 1859 and 1921 by the city population. Our chronological limits are determined by the inauguration of the first sculptural monument of the city, dedicated to Bolivar, and by the inauguration of the Monument to San Martín, in the context of the celebrations of the Centennial of Independence. In this way, we will seek not only the manifestations of apparent incomprehension and opposition to the sculptural project in progress in the Peruvian capital, but also the manifestations of support and adhesion, especially in the inauguration ceremonies. We will also try to uncover the strategies mobilized by the Peruvian State in order to disseminate practices of respectability to sculptures among the population, claiming contemplative positions for observers. We will start from a
\end{abstract}

\footnotetext{
${ }^{1}$ Mestre em História Social pela Universidade de São Paulo, sob orientação da professora Dra. Gabriela Pellegrino Soares, com dissertação intitulada Nos altares da pátria: Monumento al Combate Dos de Mayo e Monumento a Francisco Bolognesi em Lima (1866-1924). Este artigo é resultado da pesquisa realizada pelo autor no Peru, junto à Universidad Nacional Mayor de San Marcos, supervisionada pela professora Dra. Carlota Casalino Sen, entre setembro e novembro de 2018. Esta pesquisa foi realizada por meio da Bolsa de Estágio de Pesquisa no Exterior (BEPE), concedida pela FAPESP (processo FAPESP $\mathrm{n}^{\circ}$ 2018/11586-0, Fundação de Amparo à Pesquisa do Estado de São Paulo). As opiniões, hipóteses e conclusões ou recomendações expressas neste material são responsabilidade do autor e não necessariamente refletem a visão da FAPESP. Endereço para correspondência: Rua Guararema, 25, Bosque da Saúde, São Paulo (SP), CEP 04136030. Contato: rafael.scarelli@usp.br
}

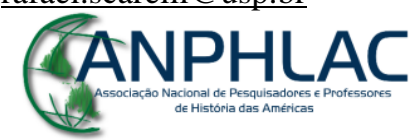

Revista Eletrônica da ANPHLAC, ISSN 1679-1061, № 27, p.310-346 , Ago./Dez., 2019.

http://revista.anphlac.org.br 
heterogeneous universe of historical sources, such as travel guide, postcards, articles published in the press and letters exchanged between municipal authorities.

Keywords: Lima, public monuments, reception.

Artigo recebido em: 18/01/2019

Artigo aprovado para publicação em: 21/08/2019

\section{Introdução}

Em 9 de dezembro de 1859, em meio à rememoração da Batalha de Ayacucho $^{2}$, puxou-se o véu tingido com as cores da bandeira peruana que cobria o primeiro monumento público de Lima, dedicado ao libertador Simón Bolívar, em um evento que contou com a presença de autoridades de Estado e bandas de música (EL COMERCIO, 9 de dezembro de 1859). Nos anos subsequentes, até as comemorações do Centenário da Independência em 1921, por meio de cerimônias similares foram inaugurados monumentos dedicados ao almirante Cristóvão Colombo (1860), ao Combate Dos de Mayo (1874), ao coronel mártir da Guerra do Pacífico Francisco Bolognesi (1905), ao libertador José de San Martín (1906), ao naturalista ítalo-peruano Antonio Raimondi (1910), ao presidente civilista Manuel Candamo (1912) e ao presidente marechal Ramón Castilla (1915). ${ }^{3}$

\footnotetext{
${ }^{2}$ Batalha ocorrida nos campos de Ayacucho, em 9 de dezembro de 1824, entre os exércitos realista e patriota, selando a independência peruana, proclamada por San Martín em 1821.

${ }^{3}$ Os dois primeiros monumentos limenhos, a Bolívar (1859) e Colombo (1860), foram obras de artistas provenientes da Península Itálica: Adamo Tadolini e Salvatore Revelli, respectivamente (Cf. VIFIAN LOPEZ, 2014). Por sua vez, o Monumento Dos de Mayo, inaugurado em 1874, foi erigido pelos artistas franceses Louis-Léon Cugnot e Edmond Guillaume. Essa obra homenageia o Combate Dos de Mayo, travado em 2 de maio de 1866, entre a esquadra naval espanhola e as repúblicas aliadas de Peru, Chile, Bolívia e Equador (Cf. MAJLUF, 1994). O Monumento a Bolognesi (1905), construído pelo escultor catalão Agustín Querol, celebra a memória do coronel Francisco Bolognesi, morto na Batalha de Arica (1880), no curso da Guerra do Pacífico (1879-1883), tendo oposto o Chile à aliança entre Peru e Bolívia (Cf. VILLEGAS TORRES, 2015, pp. 379-383; MONTEVERDE SOTIL, 2017, pp. 663-697). O Monumento a San Martín (1906) corresponde a um obelisco doado à cidade por Lorenzo Pérez Roca, obra do escultor espanhol Roselló (Cf. MEJÍA TICONA, 2013, pp. 40-41), que foi posteriormente transferido para a localidade Barranco após a inauguração em Lima de um monumento de maiores dimensões dedicado ao herói argentino em 1921, executado pelo escultor espanhol Mariano Benlliure. O Monumento a Raimondi (1910) foi obra do artista italiano Tancredi Pozzi (VILLEGAS TORRES, 2010, p. 219). De sua parte, o Monumento a Candamo (1912), cuja autoria é controversa, é atribuído ao francês Pierre Mercier por Gutiérrez Viñuales (2004) e ao italiano Libero Valente por Castrillón Vizcarra (1991, p. 346). Por fim, o Monumento a Castilla (1915) foi a primeira obra escultórica limenha saída das mãos de um escultor peruano, David Lozano (VILLEGAS TORRES, 2010).
}

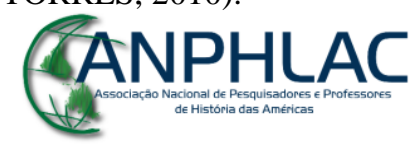

Revista Eletrônica da ANPHLAC, ISSN 1679-1061, № 27, p.310-346 , Ago./Dez., 2019.

http://revista.anphlac.org.br 
Neste artigo buscaremos tomar tais obras escultóricas por um ângulo de visão até agora pouco explorado pela historiografia. Nosso objetivo será compreender a recepção dos monumentos escultóricos erigidos em Lima pela população da capital abrangendo os limites cronológicos de 1859 e 1921, ${ }^{4}$ na dimensão das práticas dos atores urbanos. Assim sendo, não nos debruçaremos com vigor sobre a recepção das obras pela crítica de arte ou pelos círculos letrados em periódicos, mas enfocaremos os usos e apropriações que delas se fizeram no cotidiano urbano a partir de vestígios recolhidos em fontes de natureza heterogênea, tais como documentos oficiais, periódicos, guia de viagem e cartões postais. ${ }^{5}$ Dessa sorte, em vez de privilegiarmos a trajetória de edificação das obras, retomando suas origens legislativas e a organização dos concursos de projeto para eleição do artista, iniciativas que frequentemente partiram do Estado, principal agente promotor dos projetos de estatuária urbana, buscaremos pelo "outro lado" como os ditos monumentos foram recebidos pelos citadinos. Será também objetivo deste trabalho decifrar as estratégias lançadas pelas autoridades de Estado para estimular entre os observadores-transeuntes determinadas posturas consideradas respeitosas e contemplativas frente aos monumentos.

Nesse esforço, pretenderemos evitar uma apreciação dualista que contraponha de um lado o Estado, que autoritariamente teria imposto as obras escultóricas, e de outro a população limenha, que estaria necessariamente resistindo ou rejeitando essa imposição. Dessa sorte, buscaremos não apenas pelas manifestações de contestação aos projetos escultóricos em curso desde meados do século XIX, mas também pelas manifestações de

\footnotetext{
${ }^{4}$ Nossas balizas cronológicas são a inauguração do primeiro monumento público limenho, a Simón Bolívar, na Plaza del Congreso, acompanhado da implantação de doze estátuas ornamentais alegorizando os signos do zodíaco na Alameda de los Descalzos, em 1859, bem como a inauguração do Monumento a San Martín, já no bojo das comemorações do Centenário da Independência em 1921. Entendemos que o período assinalado compreende um primeiro ciclo dentro da estatuária urbana limenha, tendo antecedido ao governo de Agusto Leguía (1919-1930), marcado pelas comemorações dos centenários, que potencializaram a multiplicação de monumentos escultóricos pela cidade. Além disso, o denominado Oncenio de Leguía assistiu à inauguração do primeiro monumento público limenho dedicado a um personagem histórico indígena, Manco Cápac (1926), e promoveu a incorporação de iconografia pré-hispânica aos projetos escultóricos.

${ }^{5}$ Reconhecemos que a linha divisória entre esses dois âmbitos assinalados é bastante tênue. Com isso, explicamos que estarão excluídas deste artigo as análises das resenhas a respeito das obras e dos artistas produzidas por críticos de arte do período em tela, como Teófilo Castillo e Federico Larrañaga. Sobre esse tema, ver Villegas Torres (2006; 2010) e Monteverde Sotil (2016, pp. 313-352).
}

\section{CANPHLAC}

Revista Eletrônica da ANPHLAC, ISSN 1679-1061, № 27, p.310-346 , Ago./Dez., 2019.

http://revista.anphlac.org.br 
adesão, ou mesmo de aparente incompreensão, por parte de observadores e transeuntes, abordando a relação dos sujeitos urbanos com a estatuária pública na complexidade de suas interações.

De partida, devemos considerar as especificidades na relação entre os monumentos e o público que os singularizam frente a outras produções artísticas. Nestor García Canclini ressalta que diferentemente das obras de arte e objetos históricos acondicionados em museus, cujo sentido intrínseco é praticamente "congelado", os monumentos instalados em ruas abertas - sem a proteção de vitrines ou outros guardiões - estão sujeitos às dinâmicas da vida urbana, o que lhes insertam nas contradições do tempo presente. Dessa maneira, o entorno urbano - sinais de trânsito, edificações, cartazes publicitários - adiciona novas e mutantes camadas de sentido às obras. Questiona-se o autor a respeito de um monumento equestre a Zapata no qual o herói da Revolução Mexicana empunha uma lança: "Contra quê luta agora Emiliano Zapata, à entrada da cidade de Cuernavaca? Contra a propaganda de hotéis, bebidas e outras mensagens urbanas? Contra o trânsito denso de veículos que sugere os conflitos que hoje desafiam sua enérgica figura?" (GARCÍA CANCLINI, 2008, p. 293). A despeito de enfocar a condição dos monumentos nas cidades contemporâneas - reflexão que será retomada em nossa conclusão - Canclini ilumina o traço distintivo dessas obras escultóricas: sua interação mais dinâmica e intensa com os citadinos.

Como premissa teórico-metodológica fundamental, colhida do campo da História Cultural, compreendemos a recepção como movimento ativo por parte do sujeito, que é leitor, ouvinte ou observador. Roger Chatier, buscando borrar as fronteiras entre "produção" e "consumo", apontou para a invenção criadora dos sujeitos no cerne dos processos de apropriação e recepção. Apesar de não construírem nenhum objeto físico como a obra escultórica que se contempla -, mobilizando repertórios prévios tais sujeitos promovem a construção de sentidos que, não raras vezes, divergem daqueles pretendidos pelo autor.

Anular o corte entre produzir e consumir é antes de mais afirmar que a obra só adquire sentido através da diversidade de interpretações que constroem as suas significações. A do autor é uma entre outras, que não encerra em si a "verdade" suposta como única e permanente da obra. Dessa maneira, pode sem

\section{GANPHLAC}

Revista Eletrônica da ANPHLAC, ISSN 1679-1061, № 27, p.310-346 , Ago./Dez., 2019.

http://revista.anphlac.org.br 
dúvida ser devolvido um justo lugar ao autor, cuja intenção (clara ou inconsciente) já não contém toda a compreensão possível da sua criação, mas cuja relação com a obra não é, por tal motivo, suprimida. Definido como uma "outra produção", o consumo cultural, por exemplo a leitura de um texto, pode assim escapar à passividade que tradicionalmente lhe é atribuída. Ler, olhar ou escutar são, efetivamente, uma série de atitudes intelectuais que longe de submeterem o consumidor à toda-poderosa mensagem ideológica elou estética que supostamente o deve modelar - permitem na verdade a reapropriação, o desvio, a desconfiança ou resistência. [grifo nosso] (CHARTIER, 1990, pp. 59-60).

Manifestam-se assim as distâncias entre os projetos de estatuária urbana idealizados e concretizados pelas autoridades de Estado e pelos escultores contratados e o nível das experiências dos atores urbanos, de modo que nem sempre os citadinos tiveram posturas respeitosas e contemplativas diante das esculturas ou as interpretaram na chave de leitura esperada. A crônica publicada no diário limenho El Comercio em 1859, quando da instalação de doze estátuas ornamentais alegorizando os signos do zodíaco na Alameda de los Descalzos de Lima, capturada pela historiadora peruana Natalia Majluf (1994, p. 34), dá-nos preciosa demonstração das conflituosas e divergentes construções de sentido frente à estatuária urbana:

Yendo á [sic] pasear esta mañana muy temprano á [sic] la Alameda de los
Descalzos, fuimos sorprendidos por un cuadro muy particular. Ved si no es:
una de esas beatas de correa, que ya no es jóven [sic] porque lo fué [sic] ha
muchos años, estaba de rodillas con las manos como para decir bendito, y los
ojos enclavados en una de las estatuas. Probablemente la buena mujer creyó
que eran santos y sin más ni más se afinojó delante de ella y se pusó [sic] á
[sic] dirijirle [sic] oraciones. ¡Válgale su inocencia! ¿Quién sería el tunante que
le haria [sic] creer que esas estatuas del paganismo eran ídolos del
cristianismo? [grifo nosso] (EL COMERCIO, 29 de setembro de 1859, p. 2).

Em tom sarcástico, o cronista anônimo registrou a reação possível diante de uma novidade na paisagem urbana, uma vez que aquelas obras se constituíam no primeiro conjunto de estatuária urbana construído em Lima: até aquele momento, a escultura limenha era composta primordialmente de obras religiosas, esculpidas em madeira ou pedra, instaladas no interior de igrejas e periodicamente transportadas em procissões (BERNALES BALLESTEROS, 1991, pp. 1-133; VILLEGAS TORRES, 2010, pp. 211-245). Na dimensão das práticas, na qual os projetos idealizados pelos gestores urbanos frequentemente se confrontam com a suposta incompreensão e resistência daqueles vistos

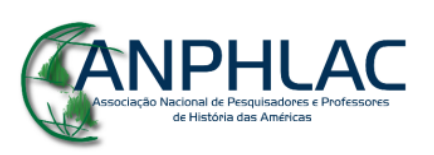

Revista Eletrônica da ANPHLAC, ISSN 1679-1061, № 27, p.310-346 , Ago./Dez., 2019.

http://revista.anphlac.org.br 
como objeto das reformas modernizadoras, os discursos enunciados são ressignificados, engendrando formas particulares de experimentação das transformações na cidade.

Por outro lado, tomaremos os monumentos abordados na perspectiva das representações do mundo social. A despeito de sua pretensão universalizante fundada na razão, ditas representações estão sempre atravessadas pelas posições e interesses dos grupos que as forjam e manipulam.

\begin{abstract}
As percepções do social não são de forma alguma discursos neutros: produzem estratégias e práticas (sociais, escolares, políticas) que tendem a impor uma autoridade à custo de outros, por elas menosprezados, a legitimar um projeto reformador ou a justificar, para os próprios indivíduos, as suas escolhas e condutas. Por isso esta investigação sobre as representações supõe-nas como estando sempre colocadas num campo de concorrências e de competições cujos desafios se enunciam em termos de poder e de dominação [grifo nosso] (CHARTIER, 1990, p. 17).
\end{abstract}

Nesse universo, a despeito de os monumentos em bronze e mármore pretenderem representar o conjunto da sociedade, ou materializarem determinados valores que deveriam ser assumidos por toda a comunidade, a exclusão de personagens históricos indígenas e da estética e iconografia pré-hispânica nos projetos escultóricos durante todo o período abarcado por esta pesquisa é reveladora dos limites do que era concebido como "nacional" pelos agente promotores da estatuária urbana. ${ }^{6}$ Desse modo, Chartier propõe que nos debrucemos sobre as "lutas de representação", arena de afrontamentos tão importante quanto a das lutas econômicas para compreensão dos conflitos sociais. Por essa chave, buscaremos calibrar nossas reflexões a respeito das manifestações de contestação e adesão aos monumentos limenhos.

Também nos é útil a formulação de Bronislaw Baczko a respeito dos imaginários ou da imaginação social. Segundo o autor, o imaginário social se torna inteligível e comunicável por meio da "produção de discursos nos quais e pelos quais se efetua a reunião das representações coletivas numa linguagem" (BACZKO, 1985, p. 311). A respeito das diversas linguagens que ditos imaginários empregam, diz-nos:

\footnotetext{
${ }^{6} \mathrm{O}$ primeiro monumento público dedicado a um personagem histórico indígena foi inaugurado apenas em 1926, dedicado ao Inca Manco Cápac, sendo uma doação da comunidade japonesa ao Centenário da Independência peruana.
}

\title{
GANPHLAC
}

Revista Eletrônica da ANPHLAC, ISSN 1679-1061, № 27, p.310-346 , Ago./Dez., 2019.

http://revista.anphlac.org.br 
Por fim, não esqueçamos que estes imaginários empregam facilmente as linguagens mais diversas: religiosa e filosófica, política e arquitetônica, etc. Apenas um último exemplo: todas as cidades são, entre outras coisas, uma projeção dos imaginários sociais no espaço. A sua organização espacial atribui um lugar privilegiado ao poder, explorando a carga simbólica das formas (o centro opõe-se à periferia, o "acima" opõe-se ao "abaixo", etc.). A arquitetura traduz eficazmente, na sua linguagem própria, o prestígio que rodeia um poder, utilizando para isso a escala monumental, os materiais "nobres", etc. (BACZKO, 1985, pp. 312-313).

Podemos perceber como os monumentos foram ferramentas importantes para a propagação e consolidação de imaginários afinados com o poder instituído. Em primeiro lugar, utilizando os mencionados "materiais nobres" até então pouco conhecidos pela cidade colonial, como o bronze e o mármore, capazes de transmitir a ideia de preciosidade e perenidade das figuras esculpidas, em uma escala igualmente infrequente - vale pontuar que o Monumento Dos de Mayo, inaugurado em 1874, constitui-se em uma coluna de aproximadamente 20 metros de altura -. Por fim, instituindo distanciamento e hierarquia a partir do desnível imposto pelo pedestal, que obriga o observador a contemplar a obra mirando para cima, desde uma posição inferiorizada.

Completando nosso conjunto de referências teóricas iniciais, mencionamos a contribuição de Ulpiano Bezerra de Meneses (2003, pp. 25-26), preocupado com a constituição da História Visual, não como feudo acadêmico, mas como "campo operacional, em que se elege um ângulo estratégico de observação da sociedade - de toda a sociedade". Meneses defende a necessidade de os historiadores tomarem em conta a visualidade como dimensão dos processos sociais, alertando para o potencial cognitivo das imagens, frequentemente subutilizadas como simples elementos ilustrativos ou reiteradores do texto escrito. Neste trabalho buscaremos tomar suas análises em consideração a fim de nos debruçarmos sobre imagens de diversas naturezas, tais como aquarela, gravuras e fotografias, inscritas em variados suportes, como cartões postais, guia de viagem e jornais.

\section{GANPHLAC}

Revista Eletrônica da ANPHLAC, ISSN 1679-1061, № 27, p.310-346 , Ago./Dez., 2019.

http://revista.anphlac.org.br 


\title{
Um pedestal vazio: explosão do Monumento a Manuel Candamo e expressões de contestação ou descaso à estatuária urbana
}

Em 7 de maio de 1923, o Inspector de Ornato Público de Lima, em uma missiva, assim se dirigiu ao prefeito da cidade:

\begin{abstract}
Señor Alcalde de este Concejo Provincial. Como no ignora Ud., existe en el ángulo sur del Parque Neptuno y con frente al Paseo Colón, parte del monumento que se erigió en ese lugar al malogrado estadista señor don Manuel Candamo; y como el aspecto que ofrece esa obra semi-destruida, no favorece el ornato de la ciudad sino, mas bien, desdice de la cultura y presentación local; me dirijo á [sic] Ud., como Inspector del Ramo, para rogarle quiera dignarse gestionar ante quien corresponda la reposición integral del mencionado monumento ó [sic] el retiro de los restos aludidos, en guarda, precisamente, del ornato público, el cual como se servirá Ud. convenir en ello, sufre desmedro con exhibición, en lugar tan central, de una obra en ruinas [grifo nosso]. (CONCEJO PROVINCIAL DE LIMA, 7 de maio de 1923).
\end{abstract}

O Inspector solicitava, desse modo, a reconstrução ou a remoção de uma escultura semidestruída de um parque da cidade, cujo aspecto ruinoso não favorecia seu ornato público. Tal autoridade se referia ao Monumento a Manuel Candamo, inaugurado dez anos antes, em setembro de 1912, e que fora alvo de um atentado meses após sua inauguração, na madrugada de 3 de maio de 1913. ${ }^{7}$ Naquela ocasião, o jornal El Comercio assim narrou o episódio e descreveu os danos causados à obra:

Los vecinos del Paseo Colón y de toda esa amplia zona de la ciudad fueron
despertados á [ sic] las tres menos cuarto de esta madrugada por una formidable
detonación, á [ $\mathrm{sic}$ ] la que siguieron varios estallidos que unas personas afirman
fueron disparos de armas de fuego y otras lijeras [ $\mathrm{sic}$ ] explosiones de dinamita.
Hechas las investigaciones del caso, se vino á [ sic] descubrir que torpes manos
criminales habían colocado una bomba en la estatua de don Manuel Candamo
y que la habían destruído [sic]. Según nuestros informes, el explosivo
empleado es una vulgar bomba de dinamita, con mecha de las de tiempo y ha
sido colocada á [sic] los pies de la estatua, sobre el pedestal. La explosión ha
logrado su fatal objeto; el pedestal de mármol y bronce, nada ha sufrido, pero
la estatua ha quedado destruida; el tronco ha sido separado de las piernas, la
mano izquierda ha volado, así como el dedo índice de la derecha, los faldones

7 O único trabalho historiográfico que pudemos identificar abordando a explosão do Monumento a Candamo mais detidamente é o de Castrillón Vizcarra (1991, p. 346), que resgatou um artigo publicado pela revista Ciudad y Campo em 1926, publicado na ocasião da inauguração da nova escultura dedicada ao ex-presidente. Porém, tal artigo não apresenta grandes informações sobre o atentado, ocorrido uma década antes. Em minhas investigações nos arquivos e bibliotecas limenhas, pude revisar as publicações contemporâneas à explosão, recuperando seu contexto histórico e possíveis origens.

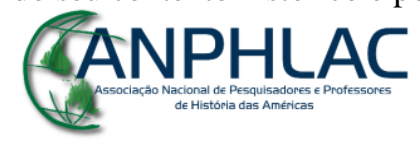

Revista Eletrônica da ANPHLAC, ISSN 1679-1061, № 27, p.310-346 , Ago./Dez., 2019.

http://revista.anphlac.org.br 
del frac y las borlas de la banda presidencial. También ha sufrido con la explosión el artístico sillón estilo imperio y el manto de mármol que acompaña la estatua (EL COMERCIO, 3 de maio de 1913, p. 1).

A reportagem do jornal limenho veio acompanhada de uma fotografia registrando o monumento após a explosão, cercado por curiosos e jornalistas. $\mathrm{Na}$ imagem podemos conferir as avarias mencionadas no fragmento anterior.

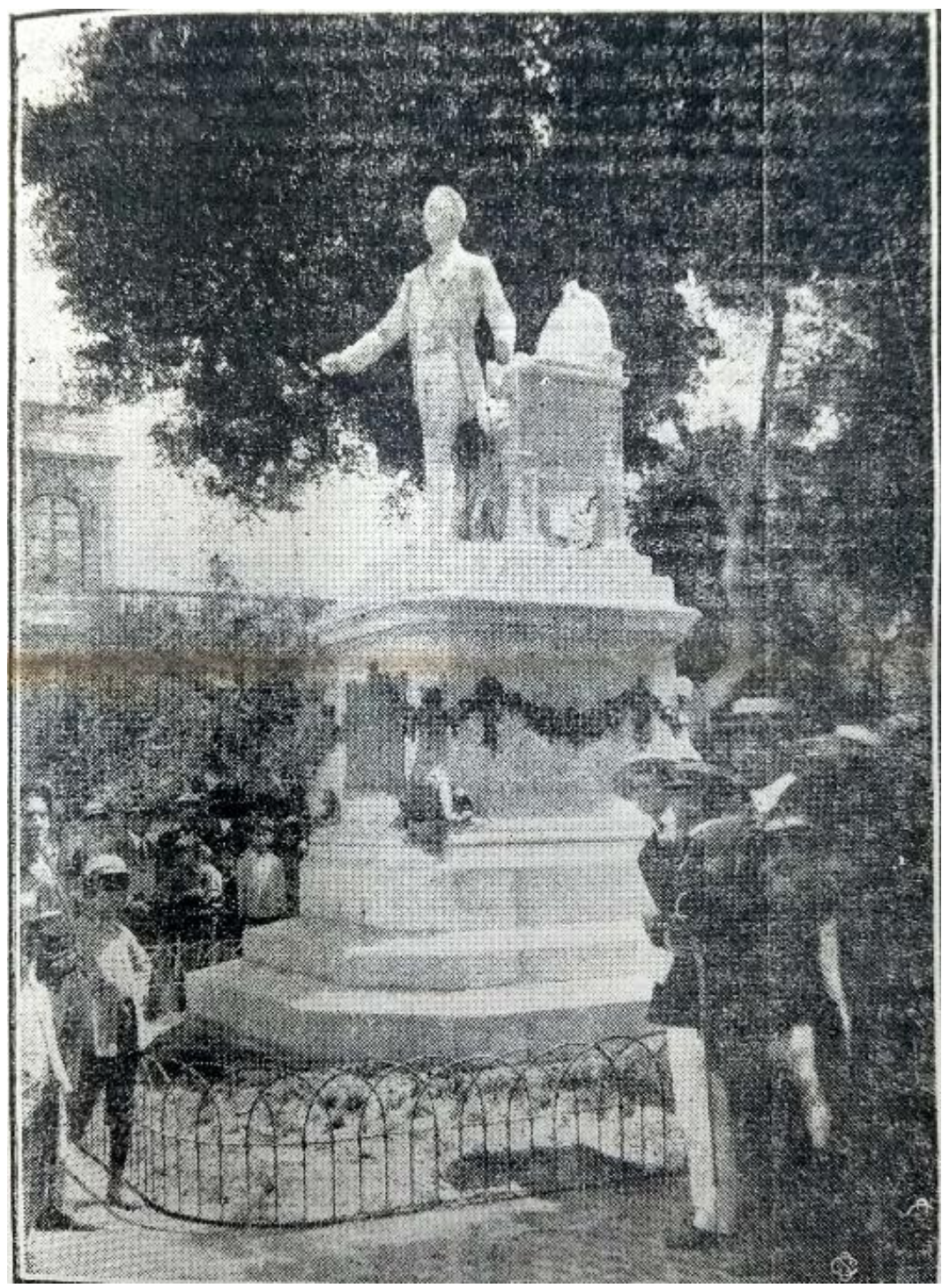

Figura 1: Monumento a Candamo após a explosão. EL COMERCIO. "Acción incalificable. La estatua de don Manuel Candamo volada con dinamita". Lima, edición de la tarde, n 33867, 3 de maio de 1913, p. 1. Instituto Riva-Agüero (IRA).

\section{GANPHLAC}

Revista Eletrônica da ANPHLAC, ISSN 1679-1061, № 27, p.310-346 , Ago./Dez., 2019. http://revista.anphlac.org.br 
O articulista se pôs então a buscar explicações para o atentado, questionando-se “ ¿cómo comprender el bárbaro atentado contra su efigie?”. Depois de revisar a trajetória de Candamo como homem público, concluiu que este, por suas virtudes, sempre recebera unânime estima, seja de seus amigos e partidários, seja de seus opositores "alejados de él por ideas o intereses políticos". Sem encontrar fundamentos para o ato criminoso, atribuio a um estrangeiro, alheio à comunidade nacional:

\begin{abstract}
Debe descartarse, pues, la idea de que se trate de una manifestación de odio llevada á [sic] ultratumba, nueve años después de que don Manuel Candamo duerme en paz el sueño eterno. [...] Quizás si mano extraña á [sic] nuestra sociedad y á [sic] nuestro medio, de esas que en otras tierras quieren llevar el pavor á los espíritus y la ruina á [sic] la colectividad, ha actuado en el acontecimiento tenebroso de esta madrugada [grifo nosso].
\end{abstract}

Apenas em 1926, durante o segundo período presidencial de Leguía (1919-1930), seria inaugurado um novo monumento a Candamo, sobre o mesmo pedestal da obra original, porém, dessa vez, sem a poltrona que o acompanhava, conhecida como "sillón de Pizarro". Nesse contexto, a revista Ciudad y Campo revisitou o episódio da explosão da estátua e, certa de que o atentado não se dirigia à memória do ex-presidente civilista, por ser este supostamente despossuído de inimigos, interpretou-o como "acto de un desequilibrado, a semejanza de los que solían practicar los nihilistas, destinados a exteriorizar encono y oposición a la Administración que se hallaba en el poder" (CIUDAD Y CAMPO, abril-maio de 1926, pp. 3-4).

É bastante difícil, preservado o anonimato do(s) responsável(eis) pela explosão, concluir as intencionalidades que permearam tal atitude. Contudo, apesar da ênfase na consensual estima por Candamo dos periódicos aqui citados, é preciso tomar em conta os significados de sua presidência e o contexto no qual se deu o atentado. Vale pontuar que o curto governo de Candamo - que faleceu um ano após ser eleito presidente, em 1904 representou o retorno do Partido Civil ao poder político no Peru, abrindo as portas a um longo ciclo designado de "segundo civilismo", interrompido brevemente pelo governo de Guillermo Billinghurst (1912-1914), que chegou ao governo central após uma jornada de mobilizações grevistas em 1912, tendo se encontrado na presidência no período da

\title{
GANPHLAC
}

Revista Eletrônica da ANPHLAC, ISSN 1679-1061, № 27, p.310-346 , Ago./Dez., 2019.

http://revista.anphlac.org.br 
explosão (MANRIQUE, 1995, p. 207). Reunindo as oligarquias peruanas, o Partido Civil deu continuidade ao processo de reconstrução nacional levado a cabo após o fim da Guerra do Pacífico (1879-1883), período denominado sugestivamente por Jorge Basadre como República Aristocrática, ${ }^{8}$ marcado por participação política restrita, tensões sociais potencializadas por crescentes mobilizações operárias e integração peruana ao capitalismo mundial monopolista sob forte dominação imperialista, primeiro britânica e logo estadunidense (MANRIQUE, 1995, p. 187). Soma-se a isso o fato de que à época da destruição do monumento - maio de 1913 - ocorriam eleições nacionais para o Parlamento peruano, marcadas por conflitos entre candidatos governistas - apoiados por Billinghurst - e oposicionistas, bem como por perturbações de rua e acusações de fraude. ${ }^{9}$ Dessa sorte, pondo em tela o contexto político-social no qual se deu o "acto de lesa cultura", a explosão da estátua de Candamo, cuja motivação não podemos desvendar, vêse agregada de novos e múltiplos significados.

A tensão pulsante àquela ocasião pode ser sentida na capa da revista ilustrada limenha Variedades, que estampou, em 31 de maio de 1913, uma aquarela de González Gamarra, na qual duas personagens dialogam diante do monumento destruído exibindo apenas o "sillón de Pizarro" vazio em chamas. Aparentemente uma autoridade local, possivelmente o prefeito de Lima Nicanor Carmona, afirma para outra figura, cuja face não podemos ver: “Junto a este sillon estaba la estatua del presidente del Perú, ahora lo han llevado para fundirlo". Ao que a outra personagem, aparentemente um estrangeiro, por sua linguagem, contesta: “Oh, yes! Comprendo. Esto de fundir presidentes debe de ser constumbre en la país". "No, mister, es la viceversa", completou Carmona.

\footnotetext{
${ }^{8}$ Este é o título dado por Basadre ao sexto tomo de sua Historia de la República del Perú. Publicada originalmente na década de 1930, a obra clássica sobre a história peruana já recebeu diversas reedições.

9 Sobre as tensões que acompanharam as eleições para o Parlamento, a revista Variedades acusou a ocorrência de fraudes em diversas localidades, a exemplo de Madre de Dios, onde os candidatos Billinghurstistas foram prejudicados. Denunciou também a existência de tumultos de rua, mencionando as “jornadas cívicas” organizadas pelo candidato à deputação obreira Justo Casaretto, que saíram tumultuando mesas de votação e constrangendo candidatos e eleitores opositores (VARIEDADES, 3 de maio de 1913).
}

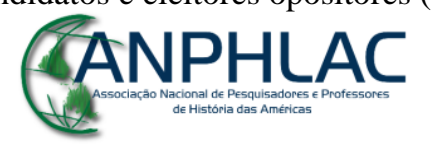

Revista Eletrônica da ANPHLAC, ISSN 1679-1061, № 27, p.310-346 , Ago./Dez., 2019.

http://revista.anphlac.org.br 


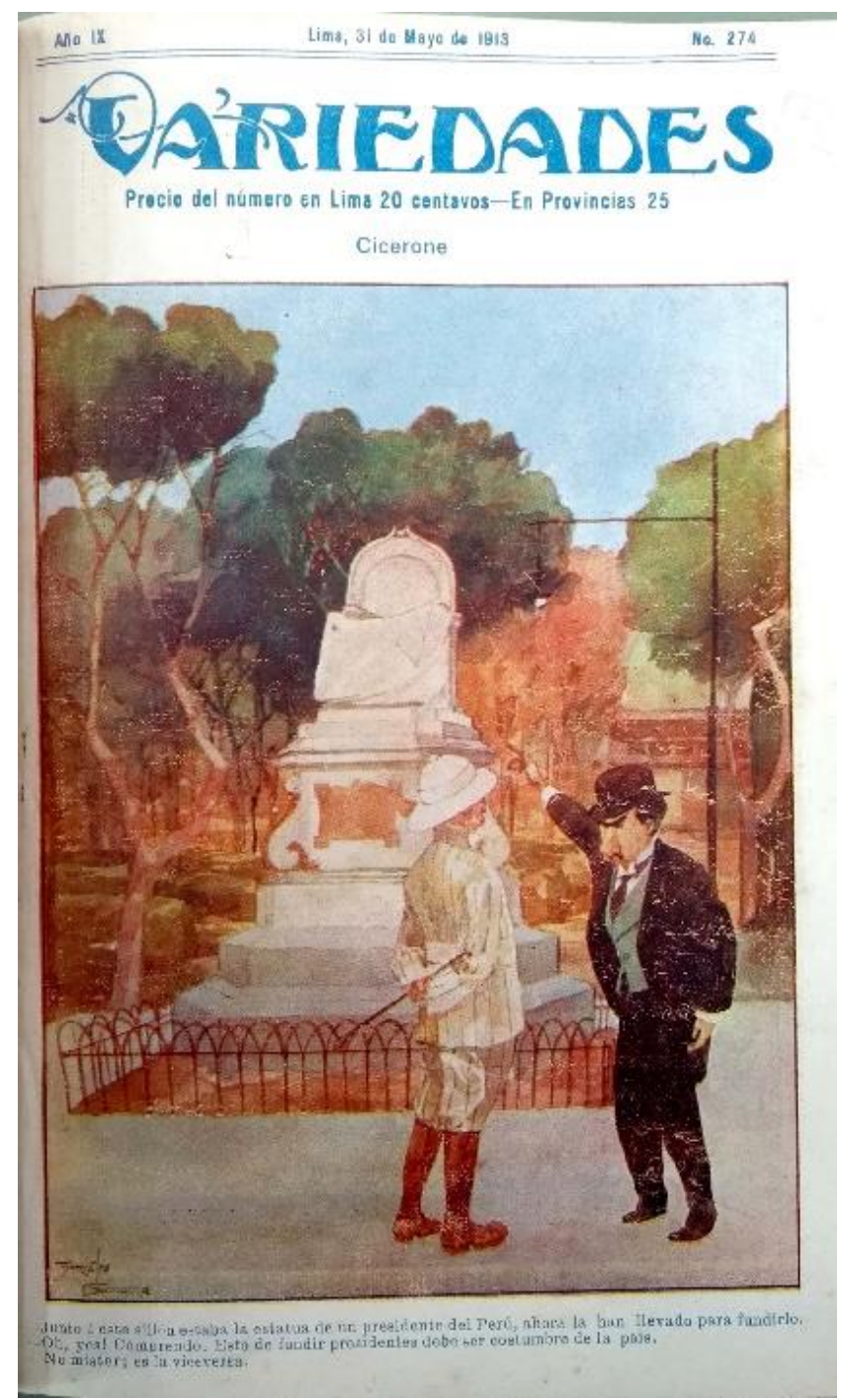

Figura 2: Aquarela de González Gamarra. VARIEDADES, ano IX, no. 274. Lima, 31 de maio de 1913. Biblioteca Nacional del Perú (BNP).

Outrossim, para além do derradeiro destino do primeiro monumento a Candamo de Lima, podemos identificar nas fontes periódicas e oficiais limenhas, outras manifestações, tanto menos extremas quanto mais cotidianas, de contestação ou descaso frente à estatuária urbana da cidade. Nessa seara, o diário El Comercio denunciou o despejo de lixo e dejetos dos cárceres junto às grades do monumento a Bolívar:

Honores a Bolívar - Nos refirimos á [sic] su estatua; pues sin duda que se la trata de honrar todos los dias [sic] de Dios amontonando junto á [sic] verja la basura que se saca de Carceletas; porque no atinamos con la intencion [sic] que se tiene al echarse, casi sobre la estatua, las inmundicias que se extraen de los calabozos de los criminales, asi [sic] va todo. Si se continúa haciendo otro

\section{GANPHLAC}

Revista Eletrônica da ANPHLAC, ISSN 1679-1061, № 27, p.310-346 , Ago./Dez., 2019.

http://revista.anphlac.org.br 
tanto todos los [días], ya llegará la vez en que no se pueda ir á [sic] admirar aquel magnifico monumento, porque no se soportan facilmente [sic] en el verano esa fetidez y mala vista que hay en los basureros. Muy poco dista de Carceletas el rio [sic], y mas [sic] racional es que se lleven allí las inmundicias y no que se depositen en la Plazuela hoy tan frecuentada con motivo de hallarse en ella la estátua [sic] tan recientemente [grifo nosso] (EL COMERCIO, 21 de janeiro de 1860, p. 2).

De sua parte, logo após a inauguração do Monumento a Cristóvão Colombo, em agosto de 1860, o governo peruano providenciou a contratação de um “cuidador" para os monumentos da cidade (VIFIAN LOPEZ, 2014, p. 100). A contratação do senhor Eugenio Richard, tão pouco tempo após a inauguração das obras, permite-nos supor que estas não atraíam apenas a admiração de observadores e transeuntes.

Con fecha 28 del pdo. mes de Septiembre, el Supremo Gobierno ha tenido a bien nombrar cuidador de las estatuas de Colón y Bolívar a D. Eugenio Richard, con el sueldo de sesenta pesos mensuales los que ha ordenado se paguen de los fondos municipales (CORREA GARAY, $1^{\circ}$ de outubro de 1860).

\section{Formando observadores: estratégias mobilizadas para fomentar respeitabilidade às obras escultóricas}

Frente a tais ocorrências, sentidas ou previstas, o governo peruano e a Municipalidade de Lima buscaram, utilizando-se de distintos meios, estimular gradualmente ou impor tacitamente aos observadores e transeuntes posturas respeitosas e contemplativas frente aos monumentos públicos.

Partindo dessa perspectiva, podemos considerar que o primeiro e mais fisicamente visível dispositivo, mobilizado já na instalação das obras, esteve na construção de grades e muros ao redor das esculturas. Como assinalou Rodrigo Gutiérrez Viñuales (2004, pp. 60-61), as estruturas que cercam os monumentos concorrem para disciplinar as posturas dos observadores, delimitando o espaço do sagrado, mas ganham função claramente defensiva à medida em que se constituem em longas barras de ferro dotadas de extremidades pontiagudas.

É o caso do Monumento a Colombo, cujas pilastras e grades que o cercavam na Alameda de Acho foram construídas em Lima. Segundo documentos do Archivo General

\section{GANPHLAC}

Revista Eletrônica da ANPHLAC, ISSN 1679-1061, № 27, p.310-346 , Ago./Dez., 2019.

http://revista.anphlac.org.br 
de la Nación, capturados pelo historiador peruano Daniel Vifian (2014, p. 96), foram contratados a Jorge Rumrill, na Fundición de la Calle del Sauce, dez lanças grandes e 400 lanças pequenas para o gradil. A fotografia a seguir nos revela o distanciamento defensivo que tais grades impunham entre o observador e a obra:

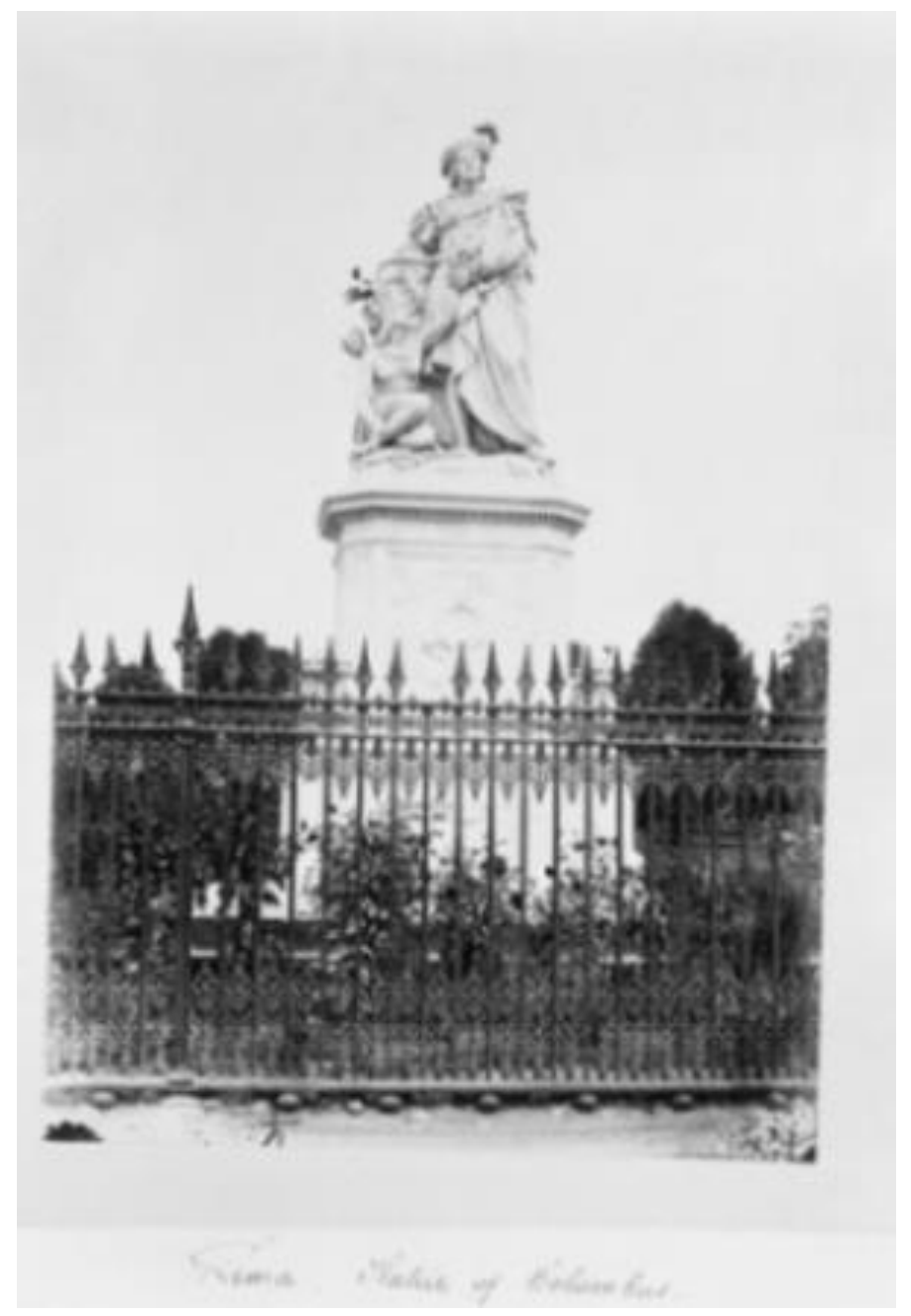

Figura 3: Monumento a Colombo, 1868, Lima. Fotografia: Eugène Courret, $9 \mathrm{~cm} \mathrm{x12} \mathrm{cm.} \mathrm{Biblioteca}$ Nacional del Perú. Colección Courret. Código de localização: 21C0425.

Em segundo lugar, esteve o recurso da vigilância aos monumentos e da repressão policial aos que praticassem atitudes delitivas contra estes, não apenas para punir os transgressores mas também impedir ou desencorajar práticas vandálicas. $\mathrm{O}$ jornal $E l$ Comercio, a respeito do Monumento a Bolívar, registrou:

\section{GANPHLAC}

Revista Eletrônica da ANPHLAC, ISSN 1679-1061, № 27, p.310-346 , Ago./Dez., 2019. http://revista.anphlac.org.br 
Plaza de Bolívar - De conformidad con lo dispuesto por la alcaldía municipal se han abierto las puertas del jardín que circunda la estátua [sic] del libertador Simón Bolívar, á [sic] fin de que diariamente sea visitado por el público. Un guardia municipal ronda todo el jardín, con el objeto de evitar que las personas mal intencionadas puedan hacer daños (EL COMERCIO, 2 de julho de 1901, p. 1).

Entretanto, a contratação de vigilantes e a construção de muros para cercar e salvaguardar os parques e praças nos quais estavam instalados os monumentos, traziam inconvenientes frente às dificuldades que impunham ao público. Em janeiro de 1860, o diário El Comercio manifestou em uma nota publicada na coluna Cronica de la capital sua inconformidade com o fechamento dos jardins da Alameda de los Descalzos ao final da tarde, horário do fim do expediente dos vigilantes. Naquela ocasião, o jardim era ornamentado com doze estátuas alegorizando os signos do zodíaco, bem como seis estátuas representando deuses gregos dispostas nas portas de acesso do passeio (VIFIAN LOPEZ, 2014, p. 6). O articulista apelava à municipalidade para a contração de mais funcionários, a fim de que, entre outras questões, o público pudesse usufruir da visão das estátuas sob o luar.

\begin{abstract}
Alameda. No cesa el público de lamentarse por la clausura contínua [sic] de este precioso paseo, ni nosotros hemos cesado de proponer á [sic] la Municipalidad medios que concilien el deseo de la sociedad con la conservacion [sic] del jardin [sic]. Como los vigilantes de la Policia [sic] se van á [sic] las cuatro dejando abandonado el paseo precisamente á [sic] la hora en que concurre la jente [sic], y esto es absurdo, creemos que la Municipalidad poseyendo como posee una Tesoreria [sic], debia [sic] encontrar muy conveniente asalariar cuatro vigilantes que no tuvieran otra ocupacion [sic] que guardar el paseo desde las cinco hasta las siete de la noche y hasta las ocho en las noches de luna, pues debe ser delicioso el parterre cuando la luna derrame su deliciosa claridad sobre las flores y las estatuas. A costa de unos cuarenta ó [sic] cincuenta pesos mensuales el público tendria [sic] la satisfaccion [sic] de ir á [sic] solazarse y pasar ratos agradables en el deleitable jardin [sic] [grifo nosso] (EL COMERCIO, 24 de janeiro de 1860).
\end{abstract}

Uma gravura dos portões de acesso da Alameda estampou o Atlas Geográfico del Perú de Mariano Paz Soldán, publicado em 1865. A imagem, reproduzida a seguir, além de registrar as grades e estátuas de deuses gregos que cercavam o jardim, representa um elegante público circulando pelo passeio, formado por casais e transeuntes acompanhados, sugerindo ser um espaço de recreio para famílias abastadas.

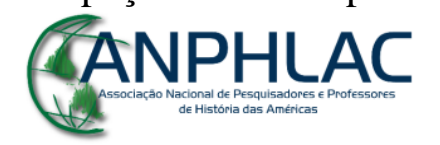

Revista Eletrônica da ANPHLAC, ISSN 1679-1061, № 27, p.310-346 , Ago./Dez., 2019.

http://revista.anphlac.org.br 


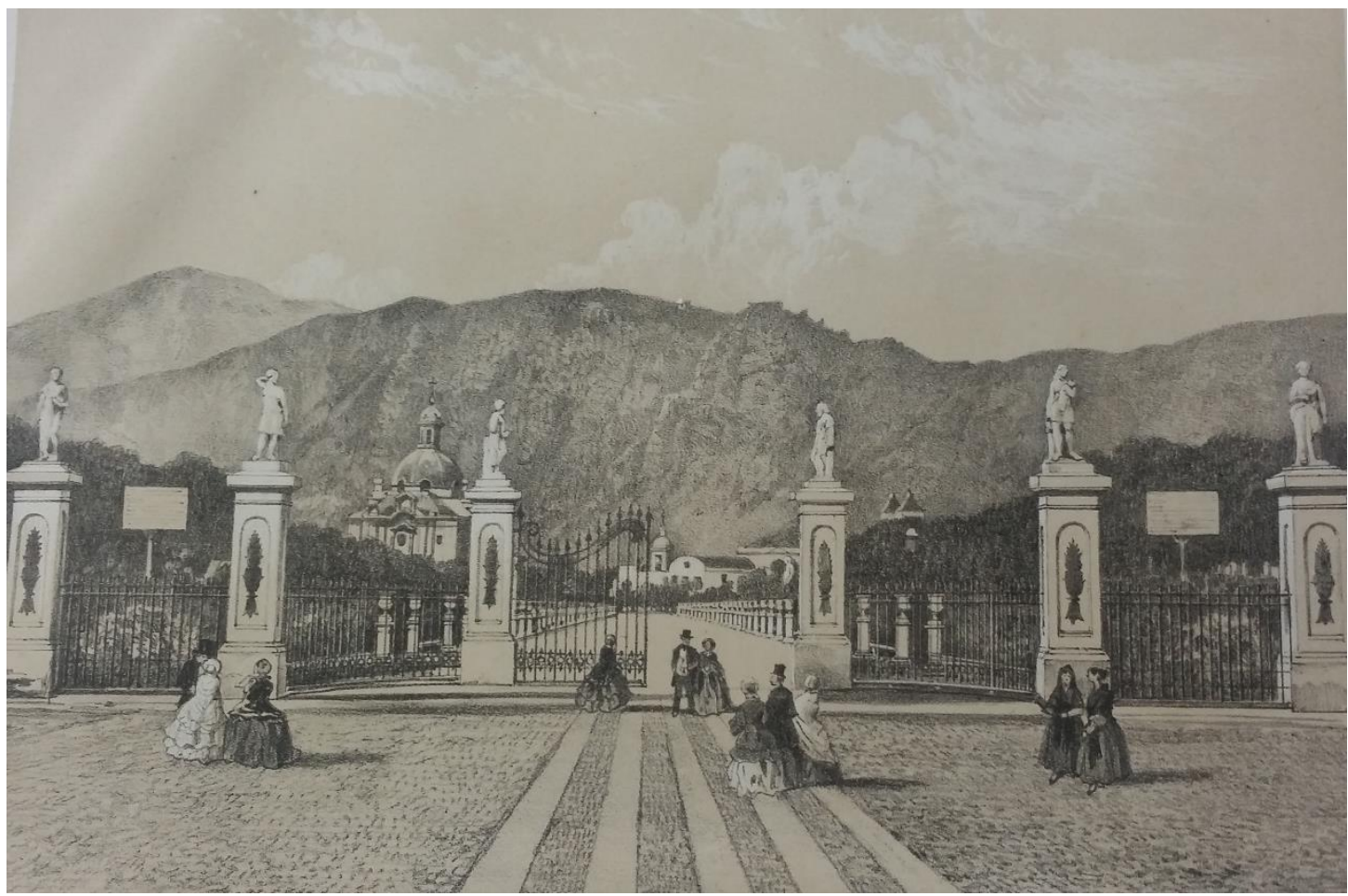

Figura 4: Alameda de los Descalzos. PAZ SOLDÁN, Mariano Felipe. Atlas Geográfico del Perú. Paris: Librería Didot Hermanos Hijos y Ca., 1865. Lâmina XXVI, "Paseo de la Alameda de los Descalzos". IRA.

Por outro lado, o esforço por parte do Estado para assegurar respeitabilidade aos monumentos públicos da cidade mobilizou também estratégias de inculcação ideológica. Dentro desse empenho, em 1930, o Director de Enseñanza assim respondeu ao prefeito de Lima, após ser exortado por este a orientar os professores no sentido de estimularem nos alunos posturas respeitosas frente às obras de ornato público da cidade:

Tengo a honra dar respuesta a su muy atento oficio No. 2158 adjuntándo [sic] el bando municipal referente a la conservación de los monumentos, estátuas [sic], fuentes, bancas, candelabros, árboles y jardines de los paseos públicos y a la prohibición de permitir dibujos y leyendas en las paredes de los edificios públicos y particulares. Efectivamente deploro admitir que las causales de estas muestras de incultura se deben en gran parte a la falta de educación adecuada y a la indiferencia de los encargados de vigilar el órden [sic] público. La Dirección de Enseñanza en diversas circulares ha llamado la atención de los maestros sobre la formación de los buenos hábitos elementales que son básicos en la vida civilizada, y en esta oportunidad con singular complacencia transcribo íntegralmente $[\mathrm{sic}]$ a los directores de las escuelas y colegios

\section{GANPHLAC}

Revista Eletrônica da ANPHLAC, ISSN 1679-1061, № 27, p.310-346 , Ago./Dez., 2019.

http://revista.anphlac.org.br 
oficiales y particulares el bando a que hago referencia. La acción conjunta del municipio, de la policía, de las escuelas y de todas las instituciones en general ha de contribuir a extirpar radicalmente el mal que señala $U d$. y que se propone combatir en nombre de la cultura de esta ciudad [grifo nosso] (CONCEJO PROVINCIAL DE LIMA, 25 de novembro de 1930).

Como podemos verificar no ofício desta autoridade, fez parte do discurso oficial associar posturas respeitosas frente às esculturas aos hábitos civilizados. No encerramento de seu ofício, o Director de Enseñanza condensou todos os mecanismos mobilizados na "luta" contra os comportamentos considerados subversivos frente à estatuária e ao patrimônio público em geral: a repressão, por meio da polícia, a conservação, por meio do município e, finalmente, a instrução dos observadores, por meio das escolas e demais instituições.

Ainda que não necessariamente tenham partido do Estado, outras iniciativas, de diferentes naturezas, estimularam respeitabilidade para com a estatuária urbana, afirmando posturas contemplativas para os citadinos. É o caso dos cartões postais exibindo monumentos e ruas da cidade nas primeiras décadas do século XX. Enquadrando os monumentos limenhos, fixavam os ângulos de visão pelos quais ditas obras deveriam ser apreciadas, ao passo que a inserção de transeuntes e observadores ao redor destas afirmava sua escala monumental e as posturas corporais aceitáveis frente às esculturas, conformando modelos de comportamento adequados.

\section{GANPHLAC}

Revista Eletrônica da ANPHLAC, ISSN 1679-1061, № 27, p.310-346 , Ago./Dez., 2019.

http://revista.anphlac.org.br 


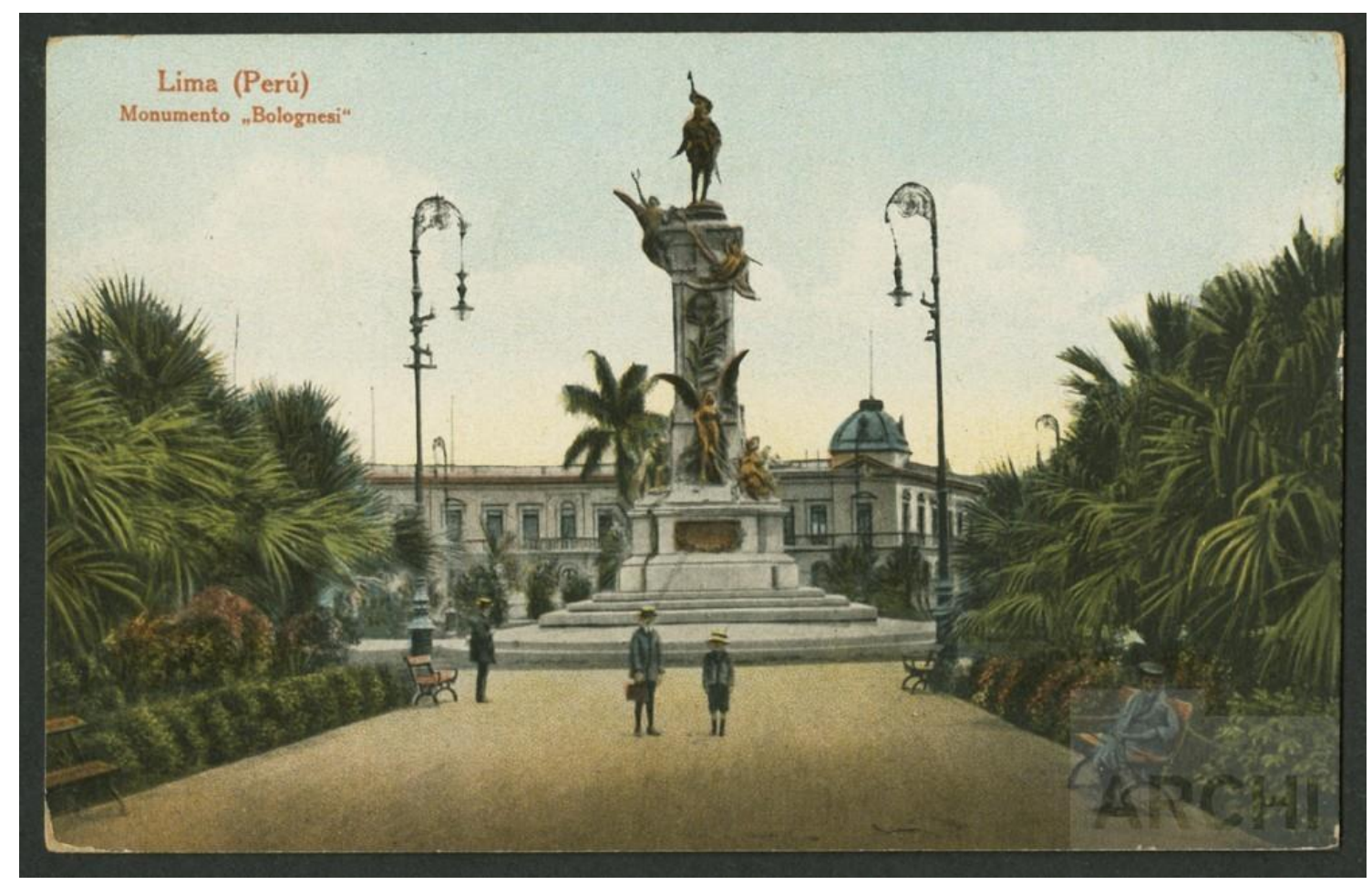

Figura 5: Cartão postal exibindo o Monumento a Bolognesi. “Lima (Perú). Monumento 'Bolognesi””, por Eduardo Polack-Schneider. Cartão postal, 8,70x13,80cm, s/d. Archivo de Arte Peruano - Museo de Arte de Lima. Disponível em: www.archi.pe Acesso: 07.10.2018.

Por fim, uma vez impressa sobre pedaços de cartolina, a imagem dos monumentos limenhos poderia circular pelo país ou mesmo pelo estrangeiro, contribuindo para alargar o raio de visibilidade da obra e chegando aos olhos daqueles que não tiveram oportunidade de cruzá-la pela cidade. Associando os monumentos aos novos ícones da modernidade urbana também representados nos postais, como as linhas de bonde e a iluminação elétrica, os postais contribuíam para afirmar o progresso da cidade aos estrangeiros bem como seus próprios habitantes.

Contudo, antes da circulação mais intensa dos mencionados postais, podem ter cumprido papel similar obras tais como guias de viagem. ${ }^{10}$ Entre estas, devemos citar o

${ }^{10}$ Cabe ressaltar o papel que tais obras tiveram não apenas de apresentar aos forasteiros os lugares relevantes a conhecer, mas também a história e as lendas locais, substituindo outras leituras ou até mesmo a visita presencial aos sítios mencionados. Em seu relato Viajes por Europa, Africa i America (1845-1847), o argentino Domingo Faustino Sarmiento descreveu a paisagem às margens do rio Sena durante a sua viagem fluvial da cidade portuária de Le Havre até Rouen, a bordo do navio Normandie, apresentando o interior de abadias e castelos medievais em ruínas (SARMIENTO, 1996, pp. 87-92). Contudo, Paul Verdevoye, nas "Notas Aclaratorias" da edição crítica da obra, ressalva que o futuro presidente argentino não esteve nos locais descritos, apoiando-se na narrativa presente no guia de viagem de Edme Théodore

\section{GANPHLAC}

Revista Eletrônica da ANPHLAC, ISSN 1679-1061, № 27, p.310-346 , Ago./Dez., 2019.

http://revista.anphlac.org.br 
Guía del viajero en Lima, escrito por Manuel Atansio Fuentes e publicado em 1861. Em sua primeira edição, junto à folha de rosto da obra, logo na primeira página, estampou-se a imagem do Monumento a Bolívar.

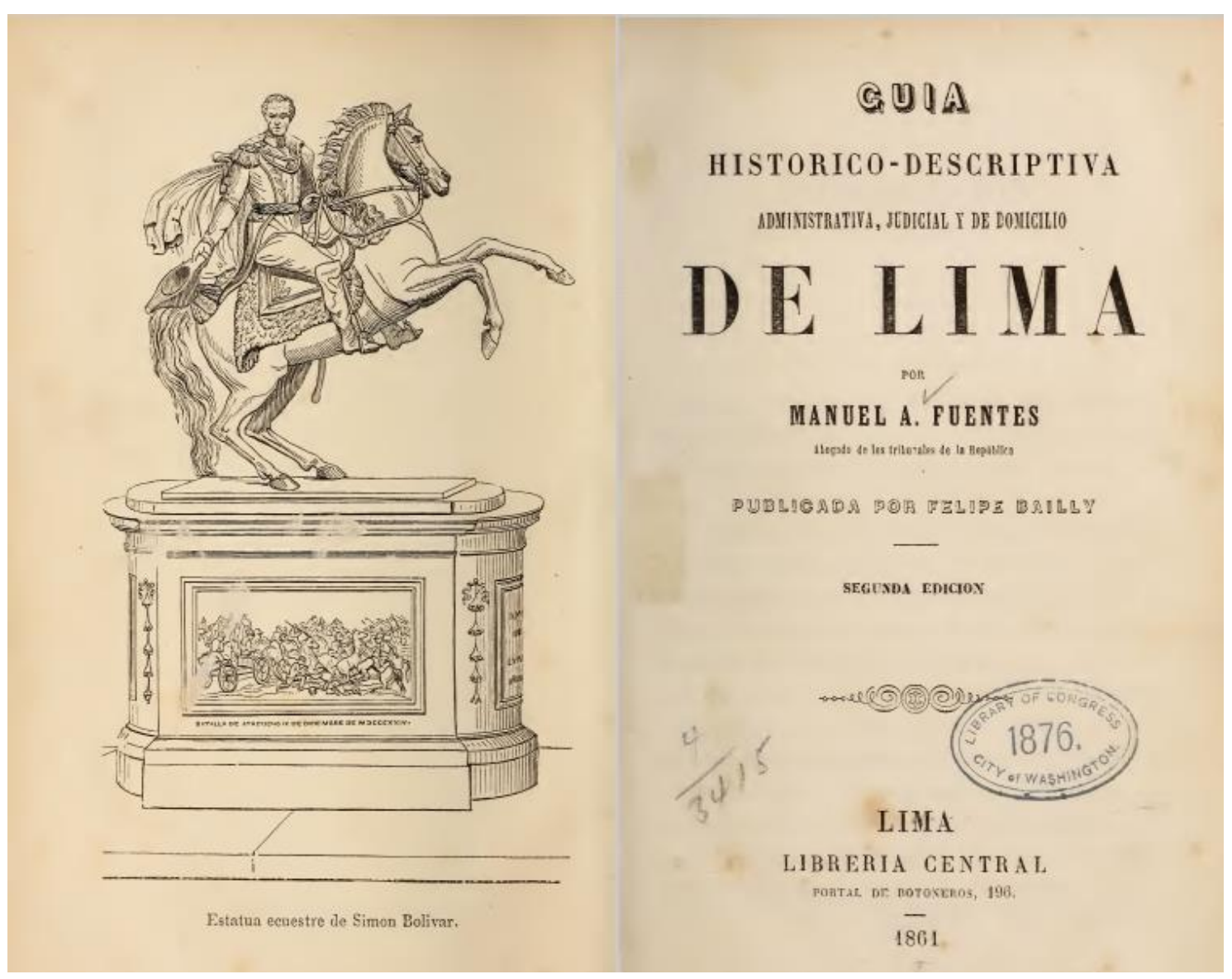

Figura 6: Frontispício do guia. FUENTES, Manuel Atanasio. Guía del Viajero en Lima. Guia Historico Descriptiva, Administrativa, Judicial y de Domicilio de Lima. $2^{\text {a }}$ Ed. Lima: Felipe Bailly, Librería Central, 1861

Nas primeiras linhas da introdução do seu Guía, Fuentes anunciou seus propósitos e o público leitor a quem se dirigia exibir aos estrangeiros o nível de civilização alcançado pela capital peruana.

Bourg (1836), do qual traduziu alguns trechos literalmente. A compra de um guia de viagem, por fim, foi registrada no seu Diario de gastos da viagem (SARMIENTO, 1996, nota 33, pp. 433-434). É interessante notar os locais que Sarmiento elegeu descrever na paisagem do Sena, monumentos associados à antiguidade da civilização europeia, como as abadias de Jumièges e Saint-Wandrille. Devo a referência que me levou à edição crítica da obra de Sarmiento ao trabalho de Stella Maris Scatena Franco, que aborda relatos de viagem de latino-americanos à Europa e aos Estados Unidos no século XIX (FRANCO, 2018, pp. 127128).

\section{GANPHLAC}

Revista Eletrônica da ANPHLAC, ISSN 1679-1061, № 27, p.310-346 , Ago./Dez., 2019. http://revista.anphlac.org.br 
La necesidad de proporcionar al extranjero los medios de conocer cuanto se encierra en una ciudad que cada dia $[s i c]$ progresa mas [sic] y mas [sic], es demasiado sentida para que no se aprecie la publicacion [sic] de un libro que le sirva de guia [sic] segura en todos los actos de la vida privada y social. No solo encontrará el forastero ligeros apuntes históricos sobre nuestros monumentos, edificios y establecimientos; no solo indicaciones exactas para cuando necesite ocurrir á $[\mathrm{sic}]$ todas las oficinas; no solo elementos para calcular sus gastos, y noticias sobre dónde y á $[s i c]$ que precios conseguirá los objetos de necesidad y de lujo, sino también ideas, aunque ligeras, de nuestras costumbres (FUENTES, 1861, p. 1).

Dessa sorte, os monumentos públicos limenhos foram apresentados como evidência da adesão do país ao progresso e à civilização a ser exibida aos estrangeiros sobretudo os europeus -. É nesse sentido que, na década de 1870, o Monumento a Colombo foi deslocado da Plazuela de Santa Ana para as portas do Palácio de Exposición, cujas instalações sediaram a Exposición Nacional de Lima de 1872, para a qual o país recebeu delegações de distintos países. Assim, como anunciou o diário El Comercio, a obra deixava seu sítio original periférico, “lejos de la vista de los extranjeros" (EL COMERCIO, 20 de agosto de 1872, p. 5). Representados como símbolos do progresso da urbe, os monumentos eram, dessa forma, inscritos nos roteiros de viajantes estrangeiros ou nacionais em visita à cidade, disseminando-se sua aceitação.

\section{Pedestal como altar: manifestações de adesão à estatuária limenha}

Se por um lado nos deparamos com expressões de contestação à estatuária pública, por outro também foram significativas as manifestações de adesão por parte da comunidade urbana. Nesse âmbito, cumpre mencionar que alguns projetos escultóricos limenhos do período assinalado tiveram seu ponto de partida em reivindicações e mobilizações da sociedade civil limenha, que foram ou não posteriormente absorvidas pelo Estado. Para compreender a atuação desses grupos de pressão, é útil nos apoiarmos na conceituação elaborada pela historiadora peruana Carlota Casalino Sen a respeito das “comunidades de culto". Perguntando-se sobre como seria possível que os heróis nacionais tivessem sua memória preservada pela coletividade após seu falecimento, a autora conclui que ditas comunidades tiveram papel central para tal façanha.

\section{GANPHLAC}

Revista Eletrônica da ANPHLAC, ISSN 1679-1061, № 27, p.310-346, Ago./Dez., 2019.

http://revista.anphlac.org.br 
Entre los elementos que contribuyen a que un héroe no sea olvidado está el hecho de que en torno a su figura se configure una "comunidad de culto". Ello porque es función primordial de esta comunidad organizar actividades y esforzarse para que se recuerden las acciones heroicas realizadas. [...] Ello significa que la vigencia del héroe en una sociedad determinada ya no recae solamente en los actos realizados por el personaje, sino que se debe - entre otras razones - al esfuerzo del grupo o círculo al que perteneció este personaje; a este grupo lo denominamos "comunidad de culto". [...] La comunidad de culto, por lo tanto, se convierte en la instancia encargada de cumplir con esa función de memoria (CASALINO SEN, 2016, pp. 103-105).

Em um primeiro momento, tais comunidades reuniram apenas o círculo mais íntimo ligado ao prócer, seus familiares e amigos para posteriormente agregarem também seu círculo profissional ou social, adquirindo a forma de associações organizadas sobre a base de uma sociedade civil, até finalmente se alargarem para toda a comunidade nacional, recebendo a bênção oficial do Estado. Podemos identificar uma estreita vinculação entre essas comunidades e os monumentos públicos, uma vez que, em alguns casos, partiu delas a iniciativa de erigi-los. Cabe mencionar aqui o Monumento a Antonio Raimondi (1910), dedicado ao naturalista de origem italiana radicado no Peru, construído pela colônia italiana residente em Lima. Segundo Villegas Torres, a comunidade italiana organizou um concurso com a finalidade de homenagear o naturalista em 1905, exclusivo, porém, a artistas italianos. A obra, executada pelo escultor Tancredi Pozzi, inaugurada em 1910 na Paza Italia, representou Raimondi observando um mineral com uma lupa (VILLEGAS TORRES, 2010, p. 219). A inauguração da escultura foi ocasião para atar os laços de solidariedade entre os membros da colônia italiana na cidade.

\footnotetext{
Ayer en la tarde fueron al domicilio de la señora Adela Loli viuda de Raimondi, los señores doctor José Boero, presidente de la sociedad de beneficencia italiana, doctor Emilio Sequi e ingeniero Emiliano Brozzi, con el fin de invitar á [sic] la familia Raimondi á [sic] la ceremonia de la inauguración del monumento que ha levantado la colonia italiana á [sic] su compatriota el sabio Raimondi. El señor Enrique Raimondi, en nombre de la familia, aceptó la honrosísima invitación, brindando una copa de champaña, con frases de afectuoso agradecimiento para la colonia italiana. El señor doctor Boero dijo, en respuesta, que la colonia que representaba él, no hacía sino cumplir un deber, honrando la memoria de un muy ilustre compatriota (EL COMERCIO, 6 de agosto de 1910, p. 1).
}

$\mathrm{Na}$ fotografia a seguir, tomada da cerimônia de inauguração e publicada na revista limenha Variedades, vê-se a multidão reunida na Plaza Italia e nas sacadas dos prédios

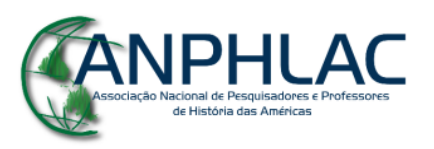

Revista Eletrônica da ANPHLAC, ISSN 1679-1061, № 27, p.310-346 , Ago./Dez., 2019.

http://revista.anphlac.org.br 
circundantes. Destaca-se também a tribuna para as autoridades, decorada com bandeiras italianas.

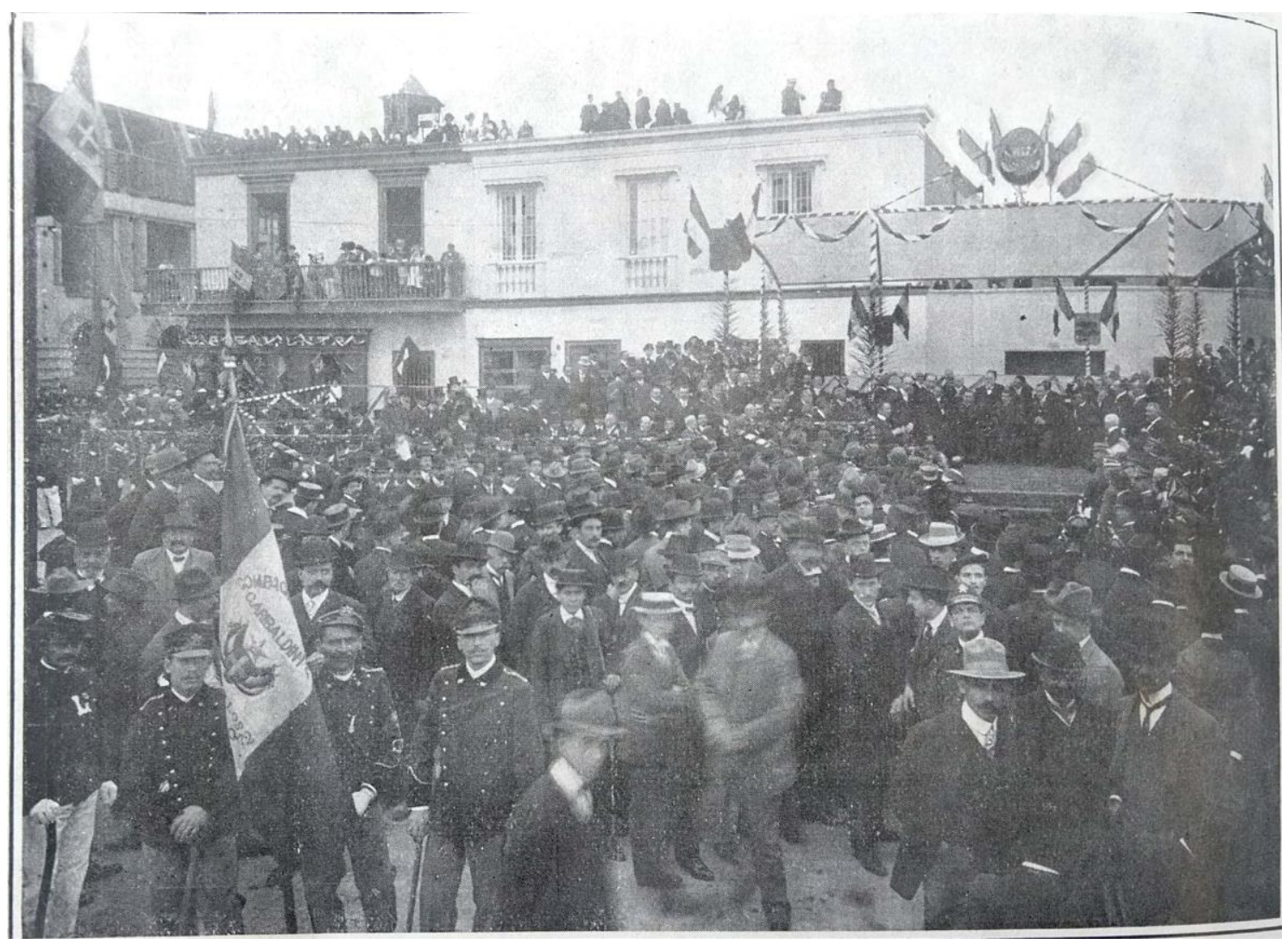

Figura 7: Inauguração do Monumento a Raimondi. VARIEDADES. "El monumento á Raymondi”. Lima, ano VI, n. 129, 20 de agosto de 1910, p. 1032. BNP.

Dentro da sociedade limenha, um importante setor que se mobilizou ao redor dos monumentos foi o dos estudantes secundaristas. Partiu de um grupo de colegiais limenhos, inspirados nos estudantes de Callao que haviam se mobilizado para a ereção de um monumento ao almirante Miguel Grau, a iniciativa de propor um monumento ao coronel da Guerra do Pacífico, Francisco Bolognesi, morto na Batalha de Arica (1880). Estudantes de colégios da capital, Liceo Internacional, Liceo Preparatorio, Colegio Barrós e Colegio Santo Tomás, sob a liderança de Luis Gálvez, fundaram a Asamblea Escolar em janeiro de 1898, convertida em Asamblea Patriótica Bolognesi, em cuja primeira reunião defenderam a construção de um monumento ao herói (CISNEROS, 1905, pp. 8-11). Rapidamente a proposta dos estudantes foi abraçada pela Municipalidade e pelo

\section{GANPHLAC}

Revista Eletrônica da ANPHLAC, ISSN 1679-1061, № 27, p.310-346 , Ago./Dez., 2019.

http://revista.anphlac.org.br 
Governo Peruano, sendo promulgado pelo presidente Eduardo López de Romaña o decreto que deu origem legal à obra em 3 de novembro de 1899.

Esse setor se mobilizou também para participar dos rituais de inauguração dos monumentos aos grandes próceres nacionais. Em junho de 1915, após a inauguração oficial do monumento ao ex-presidente marechal Ramón Castilla, organizaram um desfile pelas ruas da cidade tendo a obra escultórica como ponto de chegada (VILLEGAS TORRES, 2010, p. 241), conforme noticiou a revista Variedades.
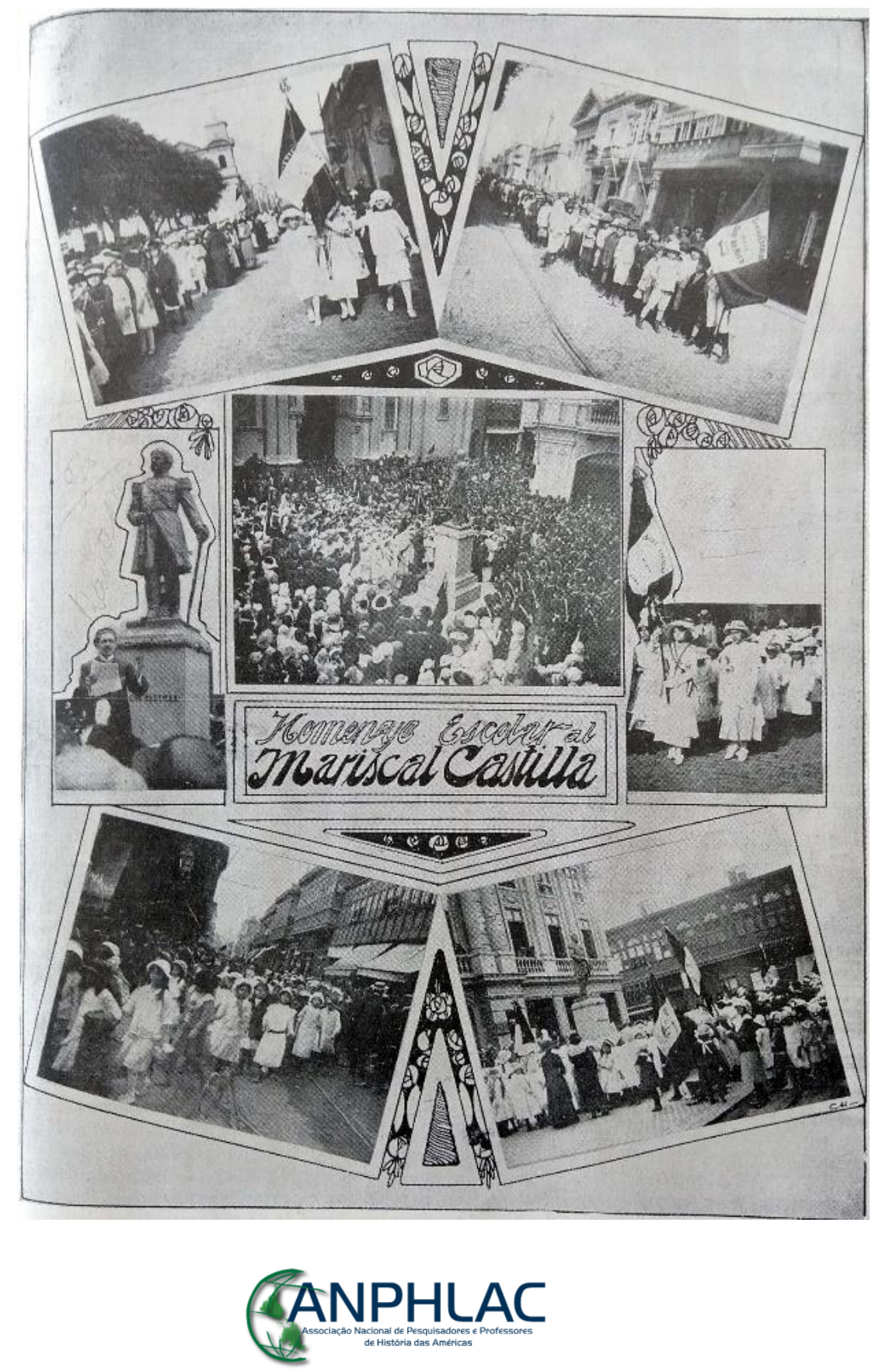

Revista Eletrônica da ANPHLAC, ISSN 1679-1061, № 27, p.310-346 , Ago./Dez., 2019. http://revista.anphlac.org.br 
Figura 8: Homenagem escolar ao Monumento a Ramón Castilla. VARIEDADES. "Homenaje escolar al mariscal Castilla". Lima, ano X, n. 381, 19 de junho de 1915, p. 2257. BNP.

Entre os monumentos públicos limenhos do período abarcado por nossa investigação, à primeira vista aquele que galgou maior adesão popular à cerimônia inaugural - em termos de enraizamento regional e social - foi o dedicado ao coronel Francisco Bolognesi, inaugurado em novembro de 1905. Podemos afirmar sem receio, porém, que este foi o monumento cuja adesão desfrutou de maior visibilidade e projeção na imprensa por meio da publicação de fotografias do evento em periódicos como $E l$ Comercio e La Prensa, e revistas como Actualidades e Prisma, desfrutando dos avanços da tipografia peruana, projeção ausente para os monumentos anteriores, inaugurados no século XIX.

O diário limenho El Comercio publicou em suas edições relações detalhadas de todas as agremiações laborais, instituições de ensino e órgãos de governo, veículos de imprensa e sociedades de beneficência, da capital e do interior, que haviam nomeado delegados para acompanhar corporativamente a cerimônia inaugural. No tocante às associações comerciais e entidades laborais, mencionam-se, entre outras, o Centro Social Obrero de Arequipa e a Sociedad Fraternal de los Artesanos de Mollendo, e entre as demais corporações, a Escuela de Agricultura, a Sociedad de Ingenieros e o Colegio de Abogados de Lima (EL COMERCIO, 4 de novembro de 1905b, pp. 1-2). Cabe aqui ressalvar, contudo, o caráter convocatório do qual se revestia a participação em tais eventos oficiais, transmitido até aos dirigentes responsáveis. Podemos localizar um indício desse viés coercitivo em uma nota publicada em El Comercio, a 4 de novembro de 1905.

Por orden del señor alcalde, comunico á [sic] las sociedades de obreros que
deberán reunirse el 6 del presente á [sic] las 12 y media en la Plaza de Bolívar,
para asistir á [sic] la inauguración del monumento á [sic] Bolognesi. Lima,
noviembre 3 de 1905 . El secretario [grifo nosso] (EL COMERCIO, 4 de novembro
de 1905 a, p. 3).

Com efeito, os preparativos para a cerimônia contribuíram para instaurar um clima de expectativa que não deixava espaço à apatia. Às vésperas da inauguração, estabelecimentos comerciais aproveitaram as festas cívicas para fazer promoções,

\section{CANPHLAC}

Revista Eletrônica da ANPHLAC, ISSN 1679-1061, № 27, p.310-346 , Ago./Dez., 2019.

http://revista.anphlac.org.br 
abaixando os preços de seus produtos, ou simplesmente divulgar anúncios publicitários associando-se ao herói ou às celebrações.

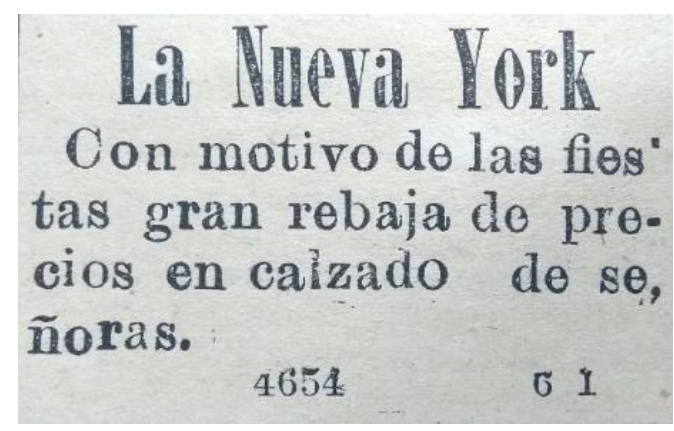

Figura 9: Anúncio da loja de calçados Nueva York. EL COMERCIO. Lima, edición de la mañana, n. ${ }^{\circ}$ $29.877,3$ de novembro de 1905 , p. 4. IRA.

Nos anos subsequentes, o monumento a Bolognesi se tornou periodicamente um centro aglutinador de manifestações. Em primeiro lugar porque logo a obra se viu associada a uma comemoração anual, sendo inscrita no calendário cívico nacional. Em novembro de 1905, por decreto do presidente José Pardo, determinou-se que os novos alistados do Exército Peruano deveriam fazer um juramento de fidelidade à Bandeira Peruana no primeiro domingo de junho de cada ano, em cerimônia pública a ocorrer na Plaza Bolognesi (EL PERUANO, 28 de novembro de 1905, p. 494).

Por sua vez, o Monumento Dos de Mayo também se vinculou a uma comemoração patriótica anual, o aniversário do Combate Dos de Mayo. A data era frequentemente celebrada com discursos laudatórios pronunciados pelos membros da Sociedad Fundadores de la Independencia y Vencedores el 2 de Mayo de $1866 .{ }^{11}$ Contudo, em 2 de maio 1916, em meio às comemorações pelo cinquentenário do combate, a festividade ganhou maiores dimensões, divididas entre a cidade portuária de Callao, palco do conflito de 1866, e Lima, onde se aglutinou no Cemitério Presbítero Maestro e no Monumento

\footnotetext{
${ }^{11}$ A Sociedad Fundadores de la Independencia foi fundada em 1848 e reorganizada em 1857, congregando os veteranos das guerras de independência, como associação privada de caráter mutualista. Posteriormente, incorporou os veteranos do Combate Dos de Mayo de 1866 e de outros conflitos, pelo que sofreu modificações em seu nome, até se estabelecer como Benemérita Sociedad Fundadores da la Independencia, Vencedores el 2 de Mayo de 1866 y Defensores Calificados de la Pátria. Paulatinamente, aproximou-se do Estado, de quem recebeu o prédio no qual funciona sua sede em 1930, sendo uma das primeiras "comunidades de culto" institucionalizadas no Peru (CASALINO SEN, 2008, pp. 213-214).
}

\section{GANPHLAC}

Revista Eletrônica da ANPHLAC, ISSN 1679-1061, № 27, p.310-346 , Ago./Dez., 2019.

http://revista.anphlac.org.br 
Dos de Mayo. Na capital as celebrações envolveram o desfile de jovens escoteiros pela Avenida La Colmena rumo ao monumento e homenagens de estudantes colegiais limenhos, reunindo uma multidão ao redor da coluna rostral de mármore, registradas nas páginas da revista Variedades.

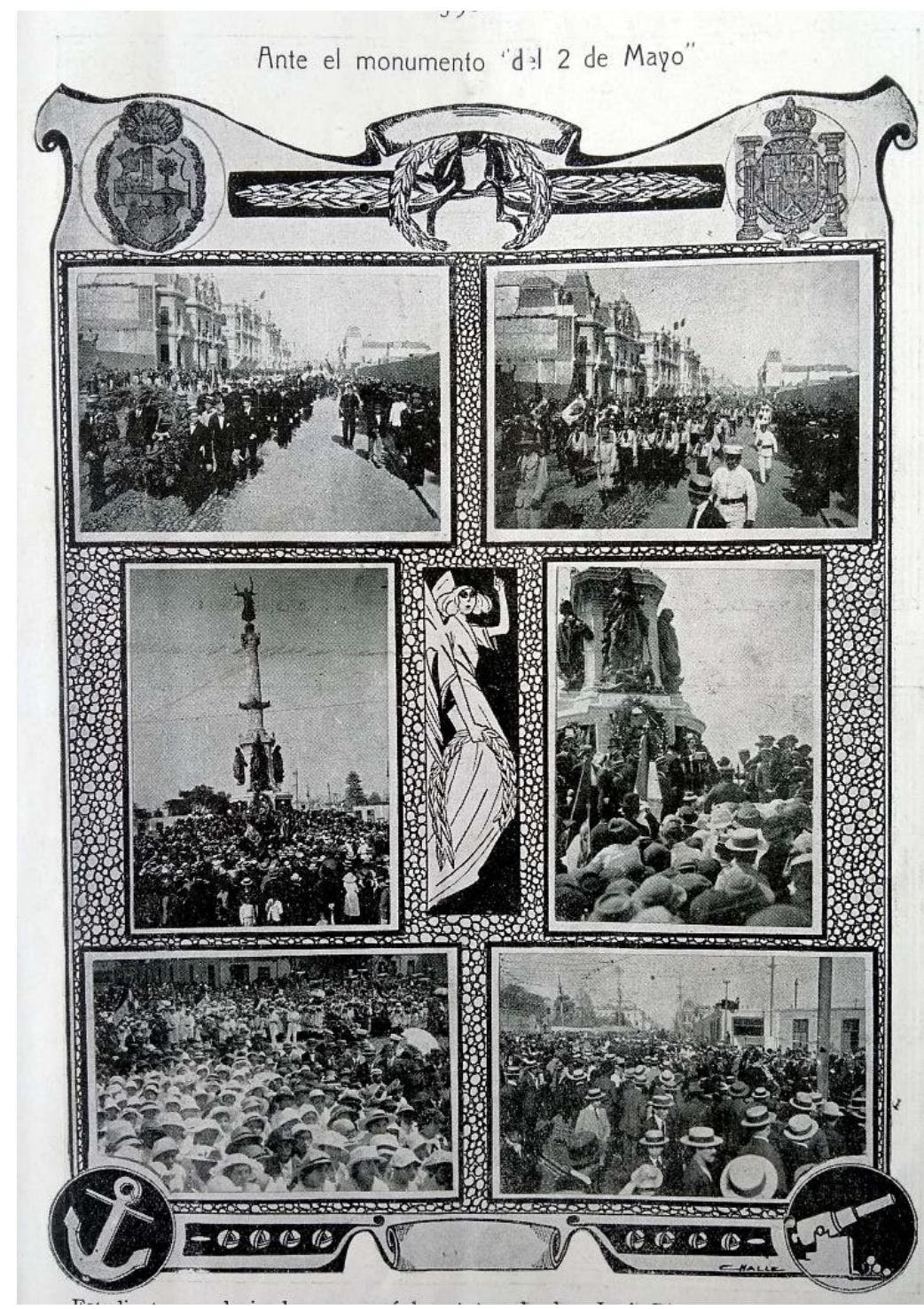

Figura 10: Celebração do $50^{\circ}$ aniversário do Combate Dos de Mayo em Lima. VARIEDADES. "El cincuentenario del 2 de mayo". Lima, año XII, n. 427, 6 de mayo de 1916, p. 591. BNP.

Para além das cerimônias oficias ou de celebrações alinhadas à ordem política vigente, os monumentos e suas praças foram palco de aglomerações relacionadas a mobilizações com pautas contestatórias ou reivindicativas frente à ordem social. Em

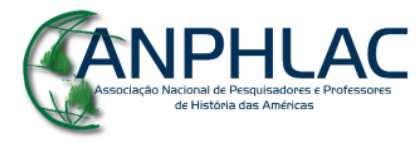

Revista Eletrônica da ANPHLAC, ISSN 1679-1061, № 27, p.310-346 , Ago./Dez., 2019.

http://revista.anphlac.org.br 
setembro de 1912, condutores dos bondes urbanos e interurbanos de Lima realizaram uma greve acusando serem vítimas de uma série de injustiças e irregularidades e apresentando reivindicações ao diretório das Empresas Electricas Asociadas. Naquela ocasião, os grevistas realizaram uma manifestação aos pés do Monumento Dos de Mayo, registrada pelas lentes dos fotógrafos (VARIEDADES, 14 de setembro de 1912, p. 1109).

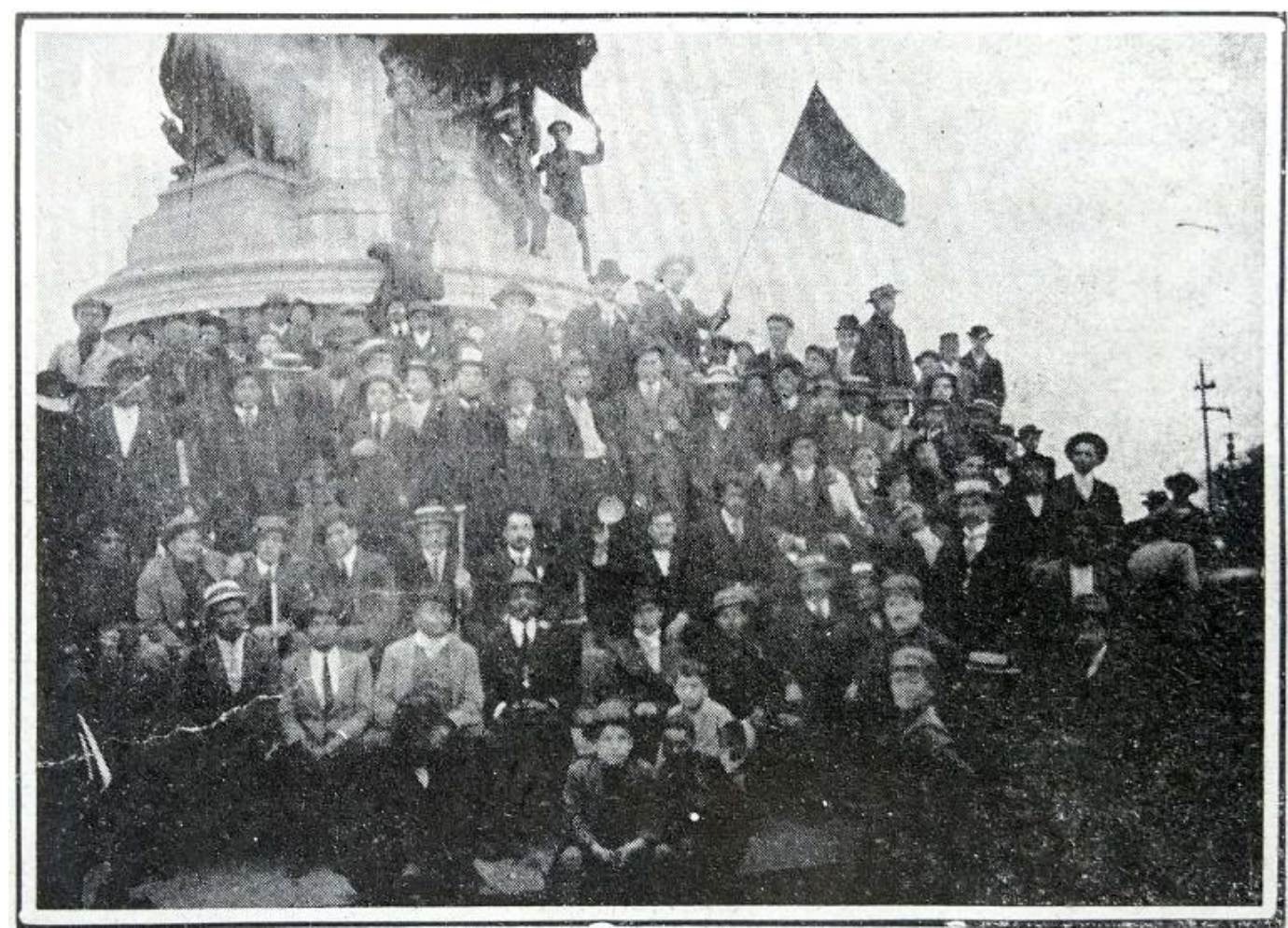

Figura 11: Concentração de motoristas grevistas na Plaza Dos de Mayo. VARIEDADES. "La Huelga". Lima, ano VIII, ${ }^{\circ} 237,14$ de setembro de 1912, p. 1109. BNP.

Analisando essa fotografia, podemos concluir que os sujeitos estão com posturas posadas para o registro fotográfico, agrupados em formação escalonada para que todos tivessem sua face capturada na imagem. Contudo, cumpre apontar para o caráter indisciplinado da presença desses personagens na praça, com algumas pessoas escalando o pedestal do monumento para balançar suas bandeiras. No ano seguinte, em 1913, na comemoração do Primeiro de Maio, Dia do Trabalhador, novamente os trabalhadores limenhos se aglomeram junto ao pedestal da coluna Dos de Mayo para um ato político, como registou Variedades:

\section{GANPHLAC}

Revista Eletrônica da ANPHLAC, ISSN 1679-1061, № 27, p.310-346 , Ago./Dez., 2019.

http://revista.anphlac.org.br 


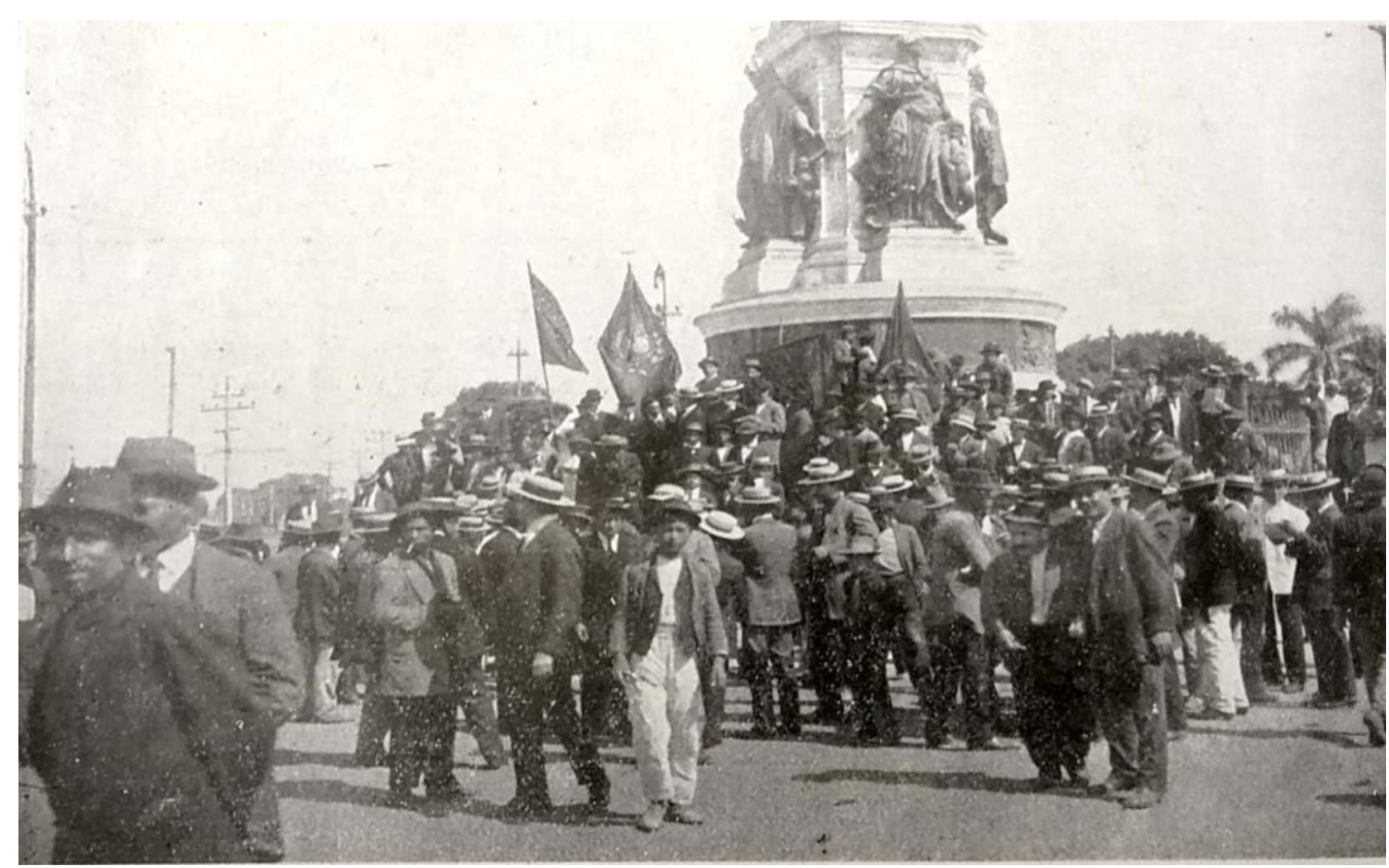

Figura 12: comemoração pelo Primeiro de Maio em 1913 na Plaza Dos de Mayo, Lima. VARIEDADES. "La fiesta del $1^{\circ}$ de mayo en Lima". Lima, ano IX, num. 270, 3 de maio de 1913, p. 2096. BNP.

A fotografia veio acompanhada de uma nota da revista anunciando que o monumento fora ponto de partida e chegada da marcha dos trabalhadores, sendo também espaço para o pronunciamento de discursos.

\begin{abstract}
También nuestros obreros, si no en su totalidad, por lo menos en apreciable porción, acostumbran hace ya algunos años, celebrar la famosa fiesta del trabajo, que en toda Europa se conmemora y que generalmente coincide con aquellas grandes huelgas generales que las Federaciones del trabajo acostumbran realizar como estímulo, festejo y demonstración de fuerza. En esta ocasión, y previas las licencias policiales del caso, los grupos obreros, desfilaron, pero sin atravesar el jirón de la Unión, como en otros años, y luego volvieron al punto de su partida en el Monumento "Dos de Mayo". Allí se pronunciaron algunos discursos, y luego en buen orden se disolvió la manifestación (VARIEDADES, 3 de maio de 1913, p. 2096).
\end{abstract}

No ano seguinte, a comemoração pelo Primeiro de Maio se reuniria na Plaza Bolognesi, aos pés do monumento ao herói de Arica (VARIEDADES, 9 de maio de 1914, p. 658). Dessa forma, concluímos que os monumentos, sobretudo Dos de Mayo e Bolognesi, que rompem a horizontalidade da cidade de princípios do século XX, localizados em

\title{
GANPHLAC
}

Revista Eletrônica da ANPHLAC, ISSN 1679-1061, № 27, p.310-346 , Ago./Dez., 2019.

http://revista.anphlac.org.br 
praças circulares na intersecção de importantes avenidas, constituíram-se em marcos de referência geográfica na urbe, ponto de encontro e de concentração para manifestações populares. Dessa sorte, mesmo as mobilizações de caráter contestatório e reivindicatório frente à ordem vigente, como a mobilização grevista de 1912 e as comemorações do Primeiro de Maio de 1913 e 1914, reconheceram tais monumentos como espaços aglutinadores, manifestando adesão ao projeto escultórico limenho, ainda que, em alguma medida, subvertendo as posturas contemplativas e respeitosas esperadas do público. ${ }^{12}$

\section{Conclusões: obras ilhadas, Monumentos públicos na contemporaneidade.}

Percorrendo as ruas de Lima nos dias de hoje, podemos avistar os monumentos que aqui apresentamos. Contudo, a cidade ao redor deles não é mais a mesma, nem lhes dirige a mesma atenção. Em meio ao descaso do poder público, muitas esculturas estão danificadas, com peças de bronze ausentes - para citar apenas o Monumento Dos de Mayo, as espadas que originalmente eram empunhadas pelas estátuas do coronel José Gálvez e pelas alegorias de Peru e Chile, além da coroa à cabeça do Equador, foram subtraídas -, ou tomadas por insetos - por sua vez, o Monumento a Bolognesi se tornou abrigo de baratas (LEÓN ALMENARA, 2 de fevereiro de 2017).

Conforme assinalou José Alonso Pereira, refletindo sobre os destinos insólitos das obras do escultor catalão Agustín Querol - autor do monumento a Bolognesi - espalhadas por distintas cidades, a city efficient do período entreguerras colocaria em questão a vigência dos monumentos comemorativos no espaço urbano, frequentemente percebidos como obstáculo para reformas viárias. Nas novas dinâmicas urbanas, instauram-se novos parâmetros de cosmopolitismo e modernidade para as cidades:

El tráfico y el transporte, la luz eléctrica y de neón, y la terciarización de usos $y$ actividades serán ya en los años veinte las auténticas referencias metropolitanas, y su concentración en puntos singulares de la Ciudad los verdaderos hitos ciudadanos, relegando definitivamente a rincones de parques y jardines el estatismo o estatuismo escultórico de las anteriores referencias cosmopolitas. [grifo nosso] (ALONSO PEREIRA, 1987, pp. 49-50).

\footnotetext{
12 Cumpre pontuar que uma das centrais sindicais mais importantes do país, a Confederación General de Trabajadores del Perú (CGTP), fundada em 1929, tem sua sede hoje na Plaza Dos de Mayo.
}

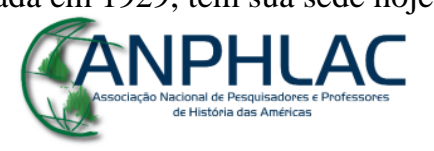

Revista Eletrônica da ANPHLAC, ISSN 1679-1061, № 27, p.310-346 , Ago./Dez., 2019.

http://revista.anphlac.org.br 
Ainda que as obras aqui estudadas não tenham sido retiradas ou deslocadas pela cidade para ceder espaço ao tráfego, as potencialidades de interação com os citadinos foram sensivelmente reduzidas. Com o crescimento de Lima, os sítios nos quais foram instalados os monumentos Dos de Mayo e Bolognesi se converteram em zonas de intenso fluxo de veículos. Uma vez que essas obras se encontram ao centro de praças circulares, rodeadas por avenidas movimentadas e desprovidas de faixas de pedestre para que os transeuntes possam alcançá-las em segurança, tornaram-se quase inacessíveis à população, ilhadas pelo trânsito.

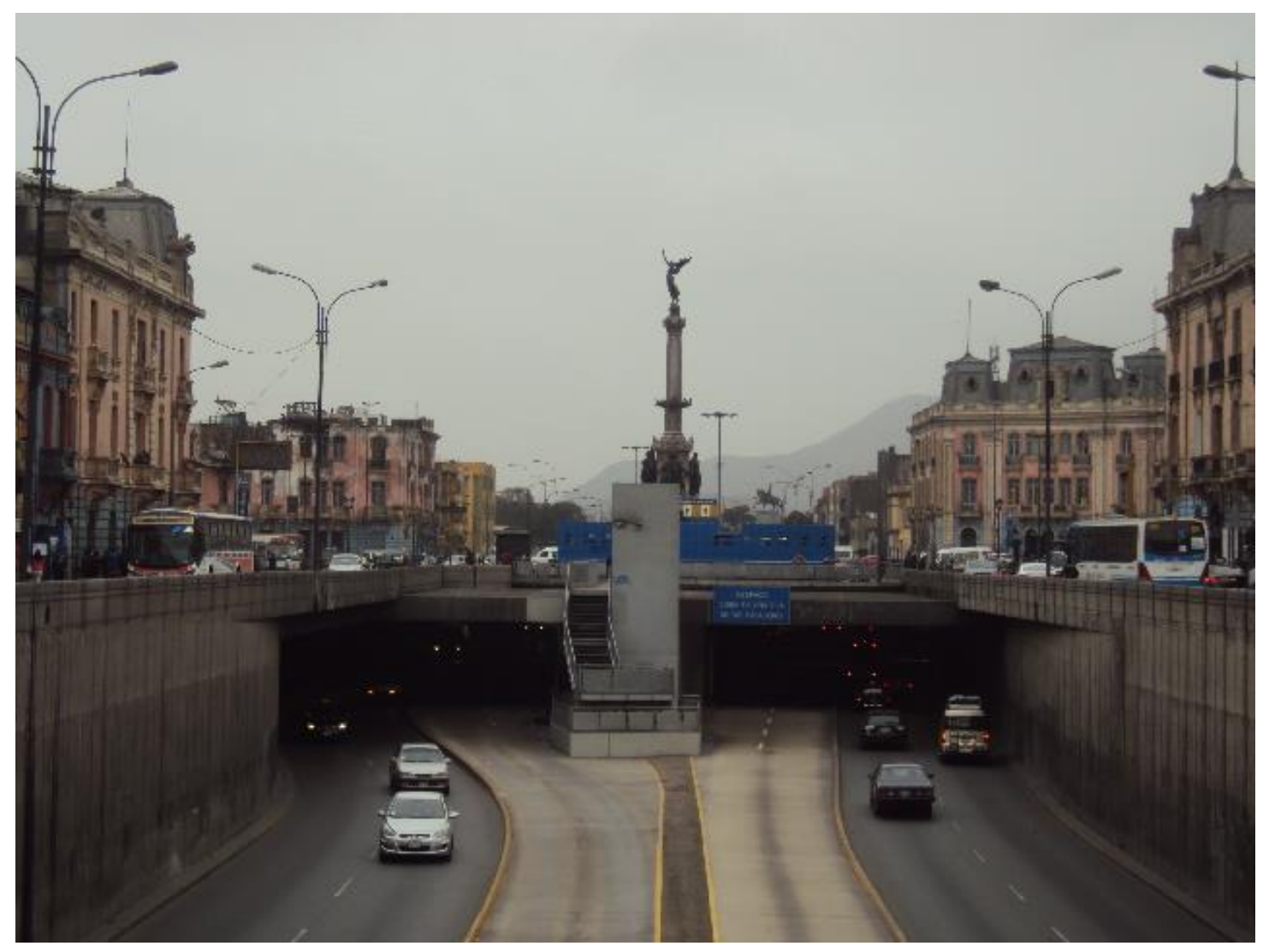

Figura 13: Vista do Monumento Dos de de Mayo. Acervo pessoal, julho de 2017.

O Monumento a Bolívar, por sua vez, apesar de se localizar em uma ampla praça - hoje conhecida como Plaza del Congreso ou Plaza Bolívar -, também está frequentemente inacessível, mas por motivos distintos. Por estar diante do palácio sede do Congresso da República, a praça onde está erigido o monumento foi cercada por grades

\section{GANPHLAC}

Revista Eletrônica da ANPHLAC, ISSN 1679-1061, № 27, p.310-346 , Ago./Dez., 2019.

http://revista.anphlac.org.br 
de ferro instaladas em suas margens que, no entanto, possuem portões de acesso. Diferentemente dos jardins da antiga Alameda de los Descalzos em meados do século XIX e da própria Plaza Bolívar em princípios do século XX, porém, esses portões estão quase sempre fechados durante o dia, impedindo a aproximação de observadores.

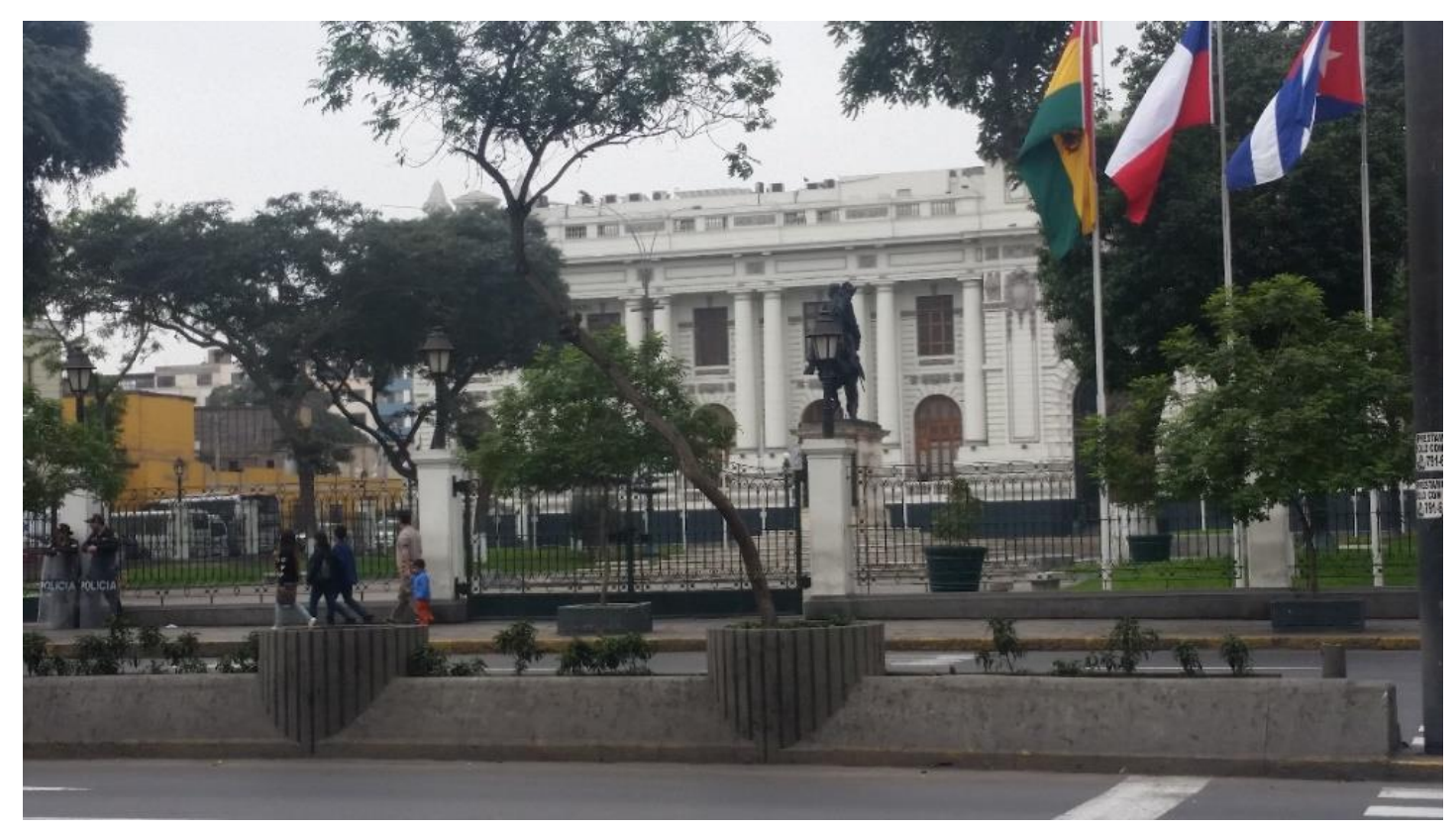

Figura 14: Monumento a Bolívar, Plaza del Congreso. Acervo pessoal, julho de 2017.

Somam-se à inacessibilidade física dos monumentos as novas dinâmicas de vivência no espaço público que se aprofundaram ao longo do século XX, a partir das quais a lógica do trânsito se impôs, convertendo as vias públicas em espaço de deslocamentos por excelência. Como pontua a antropóloga Fraya Frehse (2004, pp. 19-20), o princípio da circulação, que captura a via pública para a dinâmica do ir-e-vir despossuído de sociabilidade, dirige um olhar depreciativo aos sujeitos que permanecem imóveis na rua, o que, podemos propor, desencorajaria os transeuntes a se deterem diante das esculturas. Dessa sorte, Maurice Agulhon (1988, p. 181) conclui que as estátuas em cruzamentos e praças públicas não podem mais ser vistas, nem pelo motorista, da janela de seu automóvel em movimento, nem pelo pedestre apressado.

Diante disso, a princípio concluiríamos que se no passado os monumentos públicos limenhos despertaram estranhamento ou simpatia, foram alvo de atentados à

\section{CANPHLAC}

Revista Eletrônica da ANPHLAC, ISSN 1679-1061, № 27, p.310-346 , Ago./Dez., 2019.

http://revista.anphlac.org.br 
bomba ou cultuados como santos, aglutinaram manifestações patrióticas ou grevistas, para estes, no presente, tem imperado a indiferença. Essa conclusão, contudo, poderia mascarar um dado inescapável: a despeito de toda aparente indiferença, tais monumentos permanecem no cenário urbano, participando das mutações vividas pela cidade, sendo reapropriados e ressignificados pelos sujeitos urbanos, mediante novas modalidades de intervenção, como o grafite, ou mesmo preservando sua qualidade de pontos aglutinadores da urbe. São todos esses elementos de uma realidade complexa e multifacetada a nos sugerirem que apesar de não desfrutarem do mesmo prestígio do passado, os monumentos permanecem vigentes, interagindo com a cidade e os citadinos.

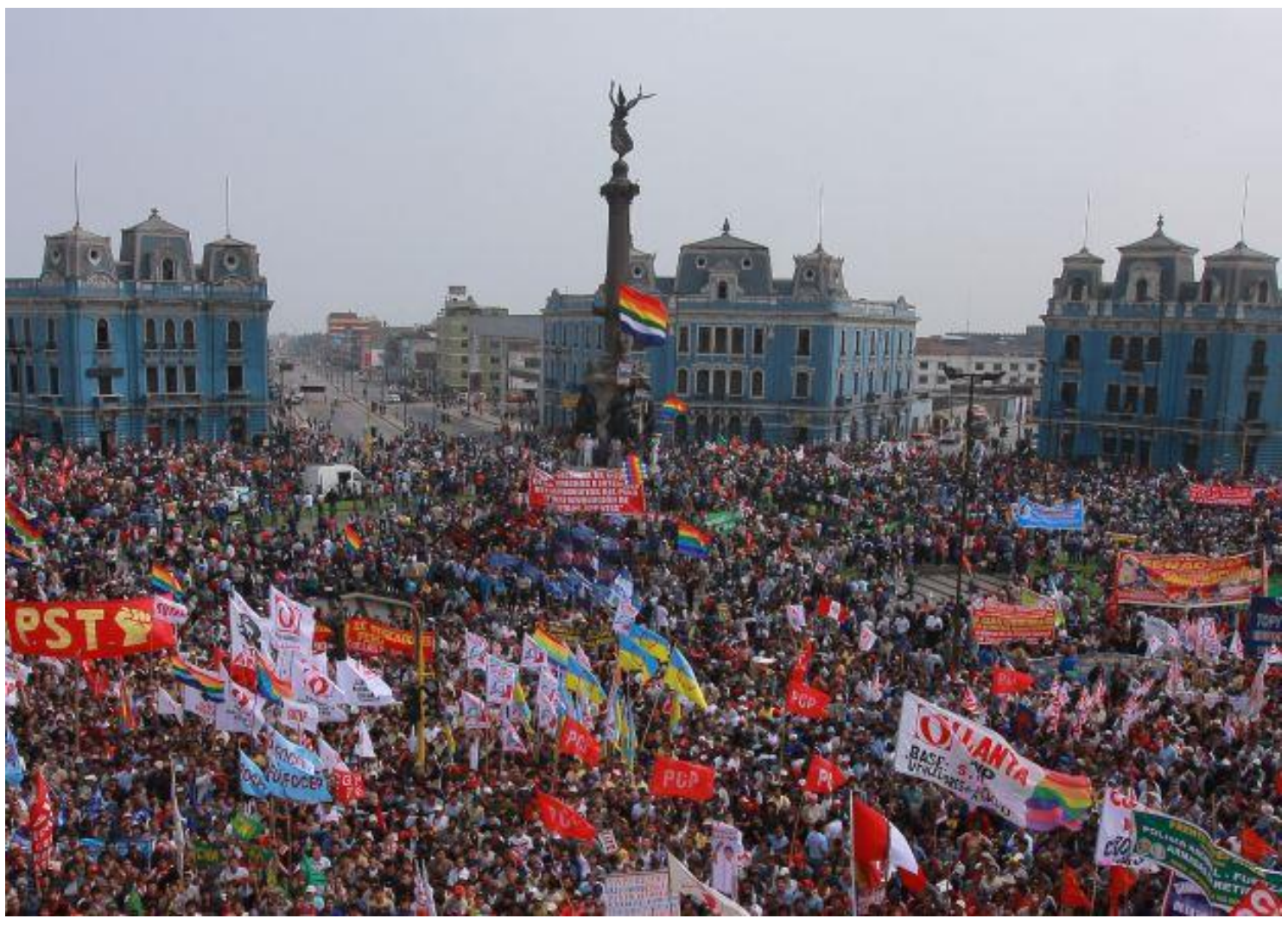

Figura 15: Manifestação de trabalhadores na Plaza Dos de Mayo, em frente à sede da Confederación General de Trabajadores del Perú, pelo Primeiro de Maio em 2013. Fonte: Publimetro. Disponível em: $<$ https://publimetro.pe/actualidad/noticia-que-se-celebra-mundo-primero-mayo-13388>. Acesso em: 01 dez. 2018.

\section{GANPHLAC}

Revista Eletrônica da ANPHLAC, ISSN 1679-1061, № 27, p.310-346 , Ago./Dez., 2019.

http://revista.anphlac.org.br 


\section{Referências Bibliográficas}

\section{Fontes}

ACTUALIDADES. "La ceremonia de la Jura de la bandera". Lima, ano IV, no 167, 9 de junho de 1906. Biblioteca Nacional del Perú (BNP).

CISNEROS, Luís Fernán. "Al descubridor del monumento". Actualidades: Revista Ilustrada. Lima, ano III, Número extraordinário, novembro de 1905, pp. 8-11. BNP.

CIUDAD Y CAMPO Y CAMINOS. "Jardines de Lima. El Parque Neptuno". Lima, no 17, abril-maio de 1926, pp. 3-4. BNP.

CONCEJO PROVINCIAL DE LIMA, Sección Archivo y Mesa de Partes. Archivado Casilla no 17. Letra O, No 3185, Fólio 531, ano 1923. "Sobre el mal estado del Monumento erigido a don Manuel Candamo". Lima, 7 de maio de 1923. Museo Metropolitano de Lima (MML).

CONCEJO PROVINCIAL DE LIMA, Sección Archivo y Mesa de Partes. Archivado Casilla No 17. Expediente Letra L, No. 299, Fólio 50, série 1, ano 1938. "Comision de Restauracion Historica de Lima solicita colaboracion de elementos intelectuales de la capital". Lima, 25 de novembro de 1930. MML.

CORREA Y GARAY, Estanislao. Correspondência do Alcalde ao Tesoureiro Municipal. Lima, $1^{\circ}$ de outubro de 1860. Archivo General de la Nación (AGN), OL-426239.

EL COMERCIO. "Paganismo". Lima, ano XXI, n 6.17129 de setembro de 1859. Instituto Riva-Agüero (IRA).

EL COMERCIO. “Inauguración. De la estátua de Bolívar". Lima, ano XXI, nº 6246, 9 de dezembro de 1859. IRA.

EL COMERCIO. "Honores a Bolívar". Lima, ano XXII, nº 6295, 21 de janeiro de 1860. IRA.

EL COMERCIO. "Cronica de la Capital. Alameda". Lima, ano XXII, nº 6.298, 24 de janeiro de 1860. IRA.

\section{GANPHLAC}

Revista Eletrônica da ANPHLAC, ISSN 1679-1061, № 27, p.310-346 , Ago./Dez., 2019.

http://revista.anphlac.org.br 
EL COMERCIO. “La estatua de Colón”. Lima, ano XXXIV, $\mathrm{n}^{\circ}$ 11.469, 20 de agosto de 1872. IRA.

EL COMERCIO. “Plaza de Bolívar”. Lima, n² 24.720, 2 de julho de 1901. IRA.

EL COMERCIO. Lima, edición de la mañana, n. ${ }^{\circ}$ 29.880, 4 de novembro de 1905. IRA.

EL COMERCIO. "La inauguración del monumento". Lima, edición de la tarde, n. 29.882, 4 de novembro de 1905. IRA.

EL COMERCIO. "La inauguración del monumento". Lima, edición especial de 16 páginas, n. ${ }^{\circ} 29.883,5$ de novembro de 1905 . IRA.

EL COMERCIO. "El monumento á Raimondi”. Lima, edición de la tarde, nº 32.477, 6 de agosto de 1905. IRA.

EL COMERCIO. "Acción incalificable. La estatua de don Manuel Candamo volada con dinamita". Lima, edición de la tarde, $\mathrm{n}^{\circ}$ 33867, 3 de maio de 1913. IRA.

EL PERUANO. Diario Oficial. "Ministerio de Guerra y Marina. Dirección de Guerra". Lima, ano 65, tomo 2, semestre 2, n 48, 28 de novembro de 1905. IRA.

FUENTES, Manuel Atansio. Guía del Viajero en Lima. Guia Historico Descriptiva, Administrativa, Judicial y de Domicilio de Lima. $2^{\text {a }}$ Ed. Lima: Felipe Bailly, Librería Central, 1861.

LEÓN ALMENARA, Juan Pablo. "Monumento a Bolognesi luce lleno de cucarachas y basura". In: El Comercio. Lima, 6 de fevereiro de 2017. Disponível em: https://elcomercio.pe/lima/monumento-bolognesi-luce-lleno-cucarachas-basura-163251 Acesso: 08.10.2018.

SARMIENTO, Domingo Faustino. Viajes por Europa, Africa i América (1845-1847), edição crítica, Javier Fernández (coord.). 2ª Ed. Madrid: ALLCA XX, 1996.

VARIEDADES. "El monumento á Raymondi”. Lima, ano VI, n. 129, 20 de agosto de 1910. BNP.

VARIEDADES. "La Huelga”. Lima, ano VIII, n 237, 14 de setembro de 1912. BNP.

VARIEDADES. "La fiesta del $1^{\circ}$ de mayo". Lima, ano IX, nº 270, 3 de maio de 1913. BNP.

\section{GANPHLAC}

Revista Eletrônica da ANPHLAC, ISSN 1679-1061, № 27, p.310-346 , Ago./Dez., 2019.

http://revista.anphlac.org.br 
VARIEDADES. Lima, ano IX, nº. 274, 31 de maio de 1913. BNP.

VARIEDADES. "Las fiestas del $1^{\circ}$ de mayo". Lima, ano X, n. 323, 9 de maio de 1914. BNP.

VARIEDADES. "Homenaje escolar al mariscal Castilla". Lima, ano X, no. 381, 19 de junho de 1915. BNP.

VARIEDADES. "El cincuentenario del 2 de mayo". Lima, ano XII, n’. 427, 6 de maio de 1916. BNP.

\section{Bibliografia}

AGULHON, Maurice. Histoire vagabonde, I. Paris: Gallimard, 1988.

ALONSO PEREIRA, José Román. “Agustín Querol y el monumento conmemorativo del novecientos". Boletín Académico - Escuela Técnica Superior de Arquitectura de La Coruña, n. 7, 1987, pp. 41-50. Disponível: 〈https://ruc.udc.es/dspace/handle/2183/5147> Acesso em: 27 nov. 2018.

BACZKO, Bronislaw. "Imaginação social”. In: ROMANO, Ruggiero (dir.). Enciclopédia Einaudi, vol. 5, Anthropos-Homem. Lisboa: Imprensa Nacional Casa da Moeda, 1985.

BASADRE, Jorge. Historia de la República del Perú, 2v. $4^{\text {a }}$ Ed. Lima: Editorial Cultura Antártica, 1949.

CASALINO SEN, Carlota. Los héroes patrios y la construcción del Estado-Nación en el Perú (siglos XIX y XX). Lima: Tese de Doutorado - Facultad de Ciencias Sociales, Universidad Nacional Mayor de San Marcos, 2008. Disponível em: <http://cybertesis.unmsm.edu.pe/handle/cybertesis/3330> Acesso em: 17 jan. 2019.

. "Comunidad de culto y construcción del héroe: la rebelión de Tacna y Francisco de Zela, 1811-1911". LOAYZA PÉREZ, Alex (ed.). La Independencia Peruana como representación: Historiografía, conmemoración y escultura pública. Lima: Instituto de Estudios Peruanos (IEP), 2016, pp. 103-133.

CASTRILLÓN VIZCARRA, Alfonso. "Escultura monumental y funerária en Lima”. In: LAVALLE, José A. Escultura en el Perú. Lima, Banco de Crédito, 1991.

CHARTIER, Roger. A História Cultural: entre práticas e representações, trad. Maria Manuel Galhardo. Lisboa: Difel, 1990.

\section{GANPHLAC}

Revista Eletrônica da ANPHLAC, ISSN 1679-1061, № 27, p.310-346 , Ago./Dez., 2019.

http://revista.anphlac.org.br 
FRANCO, Stella Maris Scatena. Viagens e relatos: representações e materialidade nos périplos de latino-americanos pela Europa e pelos Estados Unidos no século XIX. São Paulo: Intermeios; USP - Programa de Pós-Graduação em História Social, 2018.

FREHSE, Fraya. Vir a ser Transeunte: Civilidade e modernidade nas ruas da cidade de São Paulo (entre o início do século XIX e o início do século XX). São Paulo: Tese de Doutorado - Universidade de São Paulo, 2004.

GARCÍA CANCLINI, Nestor. Culturas híbridas: estratégias para entrar e sair da modernidade, trad. Ana Regina Lessa e Heloísa Pezza Cintrão. $4^{\text {a }}$ ed. São Paulo: EDUSP, 2008.

GUTIÉRREZ VIÑUALES, Rodrigo. Monumento conmemorativo y espacio público en Iberoamérica. Madrid: Ediciones Cátedra, Cuadernos de Arte, 2004.

KNAUSS, Paulo (coord.). Cidade vaidosa: imagens urbanas do Rio de Janeiro. Rio de Janeiro: Sette Letras, 1999.

MANRIQUE, Nelson. Historia de la República. Lima: Corporación Financiera de Desarrollo, 1995.

MAJLUF, Natalia. Escultura y espacio público. Lima, 1850-1879. Lima: Instituto de Estudios Peruanos, Documento de trabajo nº 67, Serie Historia del Arte no 2, 1994.

MAJLUF, Natalia. WUFFARDEN, Eduardo. La piedra de Huamanga lo sagrado y lo profano. Lima: Museo de Arte de Lima. Lima, Museo de Arte de Lima, 1998.

MENESES. Ulpiano T. Bezerra de. "Fontes visuais, cultura visual, História visual. Balanço provisório, propostas cautelares". Revista Brasileira de História. São Paulo, v. 23, $\mathrm{n}^{\mathrm{o}} \quad 45, \quad 2003, \quad$ pp. 11-36. Disponível em: <http://www.scielo.br/scielo.php?script=sci_arttext\&pid=S0102-01882003000100002> Acesso em: 17 jan. 2019.

MEJÍA TICONA, Víctor. Prefiguración de la Plaza San Martín y su Monumento (18991921). Lima: Dissertação de Mestrado - Pontifícia Universidad Católica del Perú, 2013. Disponível em: <http://tesis.pucp.edu.pe/repositorio/handle/123456789/5181> Acesso em: 17 jan. 2019.

MONTEIRO, Michelli C. Scapol. São Paulo na disputa pelo passado: Monumento à independência de Ettore Ximenes. São Paulo: Tese de Doutorado - Faculdade de Arquitetura e Urbanismo da Universidade de São Paulo, 2017.

MONTERVERDE SOTIL, Rodolfo. "El proyecto estatal para erigir el monumento al libertador José de San Martín, Lima 1904-1921”. In: LOAYZA, Alex (ed.). La

\section{GANPHLAC}

Revista Eletrônica da ANPHLAC, ISSN 1679-1061, № 27, p.310-346 , Ago./Dez., 2019.

http://revista.anphlac.org.br 
independencia peruana como representación. Historiografía, conmemoración y escultura pública. $1^{\text {a }}$ Ed. Lima: Instituto de Estudios Peruanos (IEP), 2016, pp. 313-352.

. "Política internacional de la posguerra del Pacífico, remodelación urbana y proyectos escultóricos de Lima:El monumento público a Francisco Bolognesiy los Caídos en la Batalla de Arica (1905)". Historia, Santiago, n. ${ }^{\circ}$ 50, vol. II, julhodezembro 2017, pp. 663-697. Disponível em: <http://revistahistoria.uc.cl/index.php/rhis/article/view/168> Acesso em: 17 jan. 2019.

PRADO, Maria Ligia Coelho. América Latina no século XIX: tramas, telas e textos. $2^{\text {a }}$ ed. São Paulo: EDUSP, 2014. (Estudos Latino-americanos, 2014).

SOARES, Gabriela Pellegrino. Projetos políticos de modernização e reforma no Peru: 1950-1975. São Paulo: Annablume/ FAPESP, 2000.

VILLEGAS TORRES, Fernando. El Perú a través de la pintura y crítica de Teófilo Castillo (1887-1922). Nacionalismo, Modernización y nostalgia en la Lima del 900. Lima: Asamblea Nacional de Rectores, 2006.

. "La Escultura en el 900: entre la obra europea importada y la formación de la escultura nacional". Revista del Museo Nacional, Lima, tomo L, Ministerio de Cultura del Perú, 2010, pp. 211-245.

Vínculos artísticos entre España y el Perú(1892-1929). Elementos para la construcción del imaginario nacional peruano. Lima: Fondo Editorial del Congreso del Perú, 2015.

VIFIAN LOPEZ, Daniel. Escultura civil público estatal en Lima de 1852 a 1860. Lima: Tese para o título de Licenciado en Arte - Universidad Nacional Mayor de San Marcos, 2014. Disponível em: 〈http://cybertesis.unmsm.edu.pe/handle/cybertesis/4016> Acesso em: 17 jan. 2019.

\section{GANPHLAC}

Revista Eletrônica da ANPHLAC, ISSN 1679-1061, № 27, p.310-346 , Ago./Dez., 2019.

http://revista.anphlac.org.br 